\title{
Variscan structures and their control on latest to post-Variscan basin architecture: insights from the westernmost Bohemian Massif and southeastern Germany
}

\author{
Hamed Fazlikhani, Wolfgang Bauer, and Harald Stollhofen \\ GeoZentrum Nordbayern, Friedrich-Alexander-Universität (FAU) Erlangen-Nürnberg, Schlossgarten 5, \\ 91054 Erlangen, Germany
}

Correspondence: Hamed Fazlikhani (hamed.fazli.khani@fau.de)

Received: 26 July 2021 - Discussion started: 2 August 2021

Revised: 21 December 2021 - Accepted: 16 January 2022 - Published: 24 February 2022

\begin{abstract}
The Bohemian Massif exposes structures and metamorphic rocks remnant from the Variscan orogeny in central Europe and is bordered by the Franconian Fault System (FFS) to the west. Across the FFS, Variscan units and structures are buried by Permo-Mesozoic sedimentary rocks. We integrate existing DEKORP 2D seismic reflection, well, and surface geological data with the newly acquired FRANKEN 2D seismic survey to investigate the possible westward continuation of Variscan tectonostratigraphic units and structures and their influence on latest to post-Variscan basin development. Subsurface Permo-Mesozoic stratigraphy is obtained from available wells and tied to seismic reflection profiles using a synthetic seismogram calculated from density and velocity logs. Below the sedimentary cover, three main basement units are identified using seismic facies descriptions that are compared with seismic reflection characteristics of exposed Variscan units east of the FFS. Our results show upper Paleozoic low-grade metasedimentary rocks and possible Variscan nappes bounded and transported by Variscan shear zones ca. $65 \mathrm{~km}$ west of the FFS. Basement seismic facies in the footwall of the Variscan shear zones are interpreted as Cadomian basement and overlaying Paleozoic sequences. We show that the location of normal faultbounded latest to post-Variscan late Carboniferous-Permian basins are controlled by the geometry of underlying Variscan shear zones. Some of these late Carboniferous-Permian normal faults reactivated as steep reverse faults during the regional Upper Cretaceous inversion. Our results also highlight that reverse reactivation of normal faults gradually decreases west of the FFS.
\end{abstract}

\section{Introduction}

Variscan orogenic units and structures in central and western Europe are extensively studied from disconnected exposed terranes in the Bohemian Massif, the Rhenohercynian Massif, the Black Forest and Vosges, the Armorican Massif, and the Central Iberian Zone (Franke, 2000). Between exposed Variscan units, younger sedimentary rocks obscure direct observation of possible lateral extension and architecture of Variscan tectonostratigraphy and structures. In southern Germany, for instance, Variscan units of the Bohemian Massif are correlated with exposed Variscan units in the Black Forest and Vosges, separated by ca. $300 \mathrm{~km}$, causing uncertainties in the lateral continuation and architecture of the Variscan tectonometamorphic Saxothuringian and Moldanubian zones that were originally defined by Kossmat (1927). Although a few wells provide local but valuable information about basement rock types, only a few regional 2D seismic profiles (DEKORP 84-2s and 90-3B/MVE and KTB84) image the Variscan units and structures below the sedimentary cover between the Bohemian Massif and Black Forest exposures (Franke et al., 2017; Behr and Heinrichs, 1987; Wever et al., 1990; Edel and Weber, 1995; Meissner et al., 1987; Lüschen et al., 1987).

The recently acquired FRANKEN 2D seismic survey covers the Carboniferous-Permian Kraichgau and Naab basins (Paul and Schröder, 2012; Sittig and Nitsch, 2012) and the overlying late Permian to Triassic Franconian Basin (Freudenberger and Schwerd, 1996) in the western vicinity of the Bohemian Massif in SE Germany (Fig. 1). The FRANKEN survey is tied to the DEKORP 3/MVE-90 pro- 
file creating a grid of regional seismic reflection profiles imaging exposed and buried Saxothuringian units and structures of the Variscan orogeny across the Franconian Fault System (FFS, Fig. 1). In this study we investigate the potential westward extension of Variscan tectonic units and structures and construct a first-order relationship between Variscan and post-Variscan structures and basin development. Four new seismic profiles of the FRANKEN survey are interpreted utilizing subsurface and surface geological data and are tied to the existing DEKORP-3/MVE-90 profile. Underneath the Permo-Mesozoic sedimentary cover, three main basement seismic facies (BSF1-3) are identified based on lateral and vertical changes in reflection amplitude and connectivity. Comparing seismic reflection patterns observed in exposed Variscan rocks of the Bohemian Massif with reflection patterns along the FRANKEN seismic profiles, we show a W-SW continuation of Variscan shear zones and associated Variscan allochthons. The control of Variscan shear zone geometries in strain localization influencing the latest to postVariscan basin architecture and brittle fault interactions is discussed.

\section{Geological setting}

\subsection{Variscan geodynamics and tectonic framework}

The Bohemian Massif comprises remnants of the Upper Paleozoic collision of Laurussia and Gondwana, known as Variscan mountain belt, and of the pre-Variscan basement in central Europe (Franke, 2000; Kroner et al., 2007). The Variscan orogeny has produced a wide range of metamorphic units, ranging from high-pressure and high-temperature metamorphic to low-grade metasedimentary rocks, abundant granitic intrusives, and crustal-scale shear zones and faults. From north to south, the Variscides have traditionally been subdivided into three main tectonometamorphic zones, the Rhenohercynian, Saxothuringian (including the Mid-German Crystalline High), and Moldanubian zones (Kossmat, 1927; Franke, 2000; Kroner et al., 2007). Saxothuringian and Moldanubian rocks are well exposed in the Bohemian Massif but buried by Paleozoic and Mesozoic sediments towards the west.

The Saxothuringian Zone and its westward extension, as the main area of interest, underwent three main deformational phases during the Variscan orogeny (Kroner et al., 2007 and references therein). A first deformation phase (D1) developed before $340 \mathrm{Ma}$ and records pervasive deformation during the subduction and collision, resulting in the development of recumbent folds and thrusts with top-to-thesouthwest transport direction as evidenced by kinematic indicators (Kroner et al., 2007; Stettner, 1974; Franke et al., 1992; Schwan, 1974). A second deformation phase (D2) developed due to the exhumation and juxtaposition of highpressure and ultra high-pressure metamorphic rocks in the upper crust and a ca. $45^{\circ}$ rotation in the principal subhorizontal compression direction (to NNW-SSE) after $340 \mathrm{Ma}$ (Kroner and Goerz, 2010; Schönig et al., 2020; Hallas et al., 2021; Stephan et al., 2016). The D2 deformation phase is manifested by dextral transpression of D1 structures and ductile deformation, with a generally top-to-the-northwest transport direction (Kroner et al., 2007; Franke and Stein, 2000; Kroner and Goerz, 2010; Franke, 1989). A third deformation phase (D3) records latest Variscan tectonics at $\sim 320 \mathrm{Ma}$ and is represented by the folding of synorogenic deposits during general NW-SE to NNW-SSE shortening (Hahn et al., 2010). The latest stages of D3 and the early post-Variscan are dominated by a wrench tectonic phase and the collapse of thickened crust, resulting in the development of dextral strike-slip faults initiating fault-bounded graben and halfgraben basins in central Europe, including the study area in SE Germany (Schröder, 1987; Arthaud and Matte, 1977; Krohe, 1996; Stephan et al., 2016; Ziegler, 1990; Eberts et al., 2021). Detailed and comprehensive overviews of the geodynamic and tectonostratigraphic evolution of the midEuropean Variscides have been presented by Linnemann and Romer (2010) and Franke et al. (2000).

During the earliest post-Variscan development at $<$ $305 \mathrm{Ma}$, widespread intermontane late CarboniferousPermian graben and half-graben basins, such as the NESW-trending Saar-Nahe (Henk, 1993; Stollhofen, 1998; Boy et al., 2012), Saale (Ehling and Gebhardt, 2012), Kraichgau, and Schramberg basins (Sittig and Nitsch, 2012), and NW-SE-striking basins (e.g., the Naab and Thuringian Forest basins) are formed (Paul and Schröder, 2012; Lützner et al., 2012). The Rotliegend is characterized by widespread intra-basinal volcanism, and depositional areas became enlarged across the internal parts of the Variscan Belt, e.g., in Switzerland (Matter et al., 1987), France (Chateauneuf and Farjanel, 1989; Cassinis et al., 1995; Engel et al., 1982; Laversanne, 1978; McCann et al., 2006), Germany (Henk, 1993; Stollhofen, 1998; Boy et al., 2012; Lützner et al., 2012; Sittig and Nitsch, 2012; Paul and Schröder, 2012), and Iberia (e.g., Cassinis et al., 1995). In the study area, CarboniferousPermian units are only exposed along the Franconian Fault System (FFS, also known as Franconian Line) but have been drilled by several wells located farther west in the Kraichgau and Naab basins (Fig. 1, Table 1).

In general, the top of Saxothuringian basement units beneath the sedimentary cover shows a smooth topography with a gentle southward rise, including lows along the SW$\mathrm{NE}$ axis of Würzburg-Rannungen and along the NW-SE axis of Staffelstein-Obernsees, the latter being subparallel to the FFS (Gudden, 1981; Gudden and Schmid, 1985). Saxothuringian basement lithologies drilled by the Wolfersdorf and Mittelberg wells in the north, the Eltmann well to the west, and the Obernsees well in the southeast of the study area (Fig. 1 and Table 1) are Upper Devonian to lower Carboniferous low- to medium-grade metasedimentary rocks 


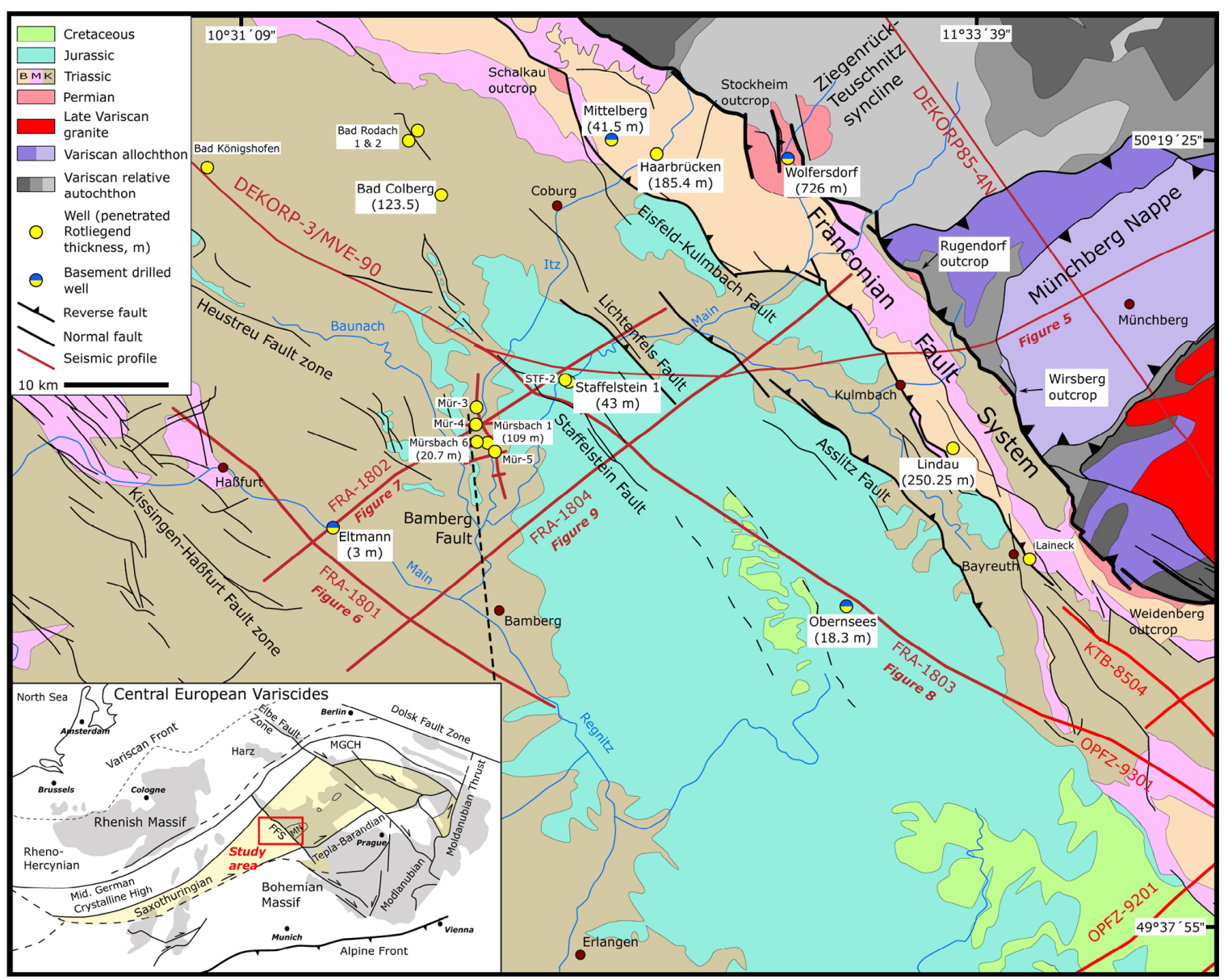

Figure 1. Location of the study area in the Saxothuringian Zone of the Variscan Orogen. The FRANKEN seismic survey is projected on geological map of the study area in dark red, creating a grid of 2D seismic profiles with existing DEKORP profiles. The main faults are shown as dark lines. The inset map shows exposed Variscan terranes in central Europe. Yellow circles show deep wells in the study area. FRA stands for FRANKEN, MGCH stands for Mid-German Crystalline High, FFS stands for Franconian Fault System, MN stands for Münchberg Nappe, Mür stands for Mürsbach, and STF stands for Staffelstein.

(Hahn et al., 2010; Stettner and Salger, 1985; Trusheim, 1964; Specht, 2018; Friedlein and Hahn, 2018).

\subsection{Latest to post-Variscan stratigraphic and structural architecture}

Carboniferous-Permian units in the study area dominantly comprise clastic continental sediments deposited in faultbounded basins outcropping in the Schalkau, Stockheim, Rugendorf, Wirsberg, and Weidenberg areas (Schröder, 1987). Thicknesses are highly variable, ranging from about 100 to $>700 \mathrm{~m}$ in the Kraichgau Basin and from about 100 up to $>1400 \mathrm{~m}$ in the Naab Basin adjacent to the FFS (Gudden, 1981; Paul and Schröder, 2012). In the Stockheim outcrop, the Wolfersdorf well is drilled into $726 \mathrm{~m}$ of Rotliegend, excluding an unknown amount of eroded section (Fig. 1 and Table 1). In the center of the study area, $109 \mathrm{~m}$ of Rotliegend was encountered by the Mürsbach 1 well (Gud- den, 1981), whereas the Mürsbach 6 and Staffelstein 1 wells only penetrated ca. 20 and $43 \mathrm{~m}$ into the upper parts of the Rotliegend (Table 1). The Eltmann well, located in a basin marginal position, encountered only $3 \mathrm{~m}$ of Rotliegend (Table 1, Trusheim, 1964). Towards the SE of the study area, the Obernsees well encountered $18.3 \mathrm{~m}$ of Rotliegend overlying metasedimentary basement rocks (Table 1, Helmkampf, 2006; Ravidà et al., 2021). However, ca. $19 \mathrm{~km} \mathrm{NE}$ of the Obernsees well, the Lindau 1 well drilled $250.25 \mathrm{~m}$ of Rotliegend strata without reaching their base (Fig. 1, Table 1; Freudenberger et al., 2006). Compared to the Rotliegend, the Zechstein tends to be of more uniform thickness mainly comprising of clay, sandstone, dolomites, and thin layers of anhydrite (Schuh, 1985). Drilled Zechstein thicknesses are $117 \mathrm{~m}$ in the Eltmann well, $126 \mathrm{~m}$ in the Mürsbach 1 well, $107 \mathrm{~m}$ in the Staffelstein well, and $104.9 \mathrm{~m}$ in the Obernsees well (Table 1). Refraction seismic surveys in the south of the study area (Nürnberg area) proved the existence 
Table 1. Deep wells in the study area with formation tops used in seismic horizon interpretation of FRANKEN seism survey. See Fig. 1 for well locations. TD stands for total depth.

\begin{tabular}{|c|c|c|c|c|c|c|c|c|c|}
\hline Well & Quaternary & Jurassic & Keuper & Muschelkalk & Buntsandstein & Zechstein & Rotliegend & Basement & $\mathrm{TD}(\mathrm{m})$ \\
\hline Obernsees & 0 & 140 & 483 & 178.35 & 417.15 & 104.9 & 18.3 & 48.3 & 1390 \\
\hline Mürsbach 01 & 26 & 0 & 300 & 224 & 524 & 126 & 109 & - & 1309 \\
\hline Mürsbach 03 & 0 & 0 & 384.4 & 212.6 & 551 & 87 & - & - & 1235 \\
\hline Mürsbach 04 & 0 & 0 & 345.6 & 210.5 & 548.3 & 73.6 & - & - & 1178 \\
\hline Mürsbach 05 & 15.6 & 0 & 338.1 & 214.7 & 559 & 56.6 & - & - & 1184 \\
\hline Mürsbach 06 & 0 & 0 & 338.3 & 210.7 & 530.7 & 121.6 & 20.7 & - & 1222 \\
\hline Staffelstein 1 & 9 & 102 & 530.2 & 239.8 & 572.2 & 103.8 & 43 & - & 1600 \\
\hline Staffelstein 2 & 8 & 104 & 532 & 235 & 301 & - & - & - & 1180 \\
\hline Eltmann & 9.4 & 0 & 178.6 & 235 & 510 & 114 & 3 & 94 & 1144 \\
\hline Lindau & 0.25 & 0 & 0 & 0 & 182.05 & 98.05 & 250.25 & - & 530.6 \\
\hline Laineck & 3.5 & 0 & 409.5 & 179 & 488 & 42 & - & - & 1122 \\
\hline Haarbrücken & 6 & 0 & 0 & 0 & 199 & 109.5 & 185.4 & - & 499.9 \\
\hline Mittelberg & 0 & 0 & 0 & 0 & 405.5 & 75.5 & 41.5 & 100.5 & 623 \\
\hline Bad Rodach 1 & 0 & 0 & 130 & 266 & 256 & - & - & - & 652 \\
\hline Bad Rodach 2 & 0 & 0 & 211.7 & 257.1 & 526.2 & 20 & - & - & 1015 \\
\hline Bad Königshofen & 3.5 & 0 & 56.5 & 251 & 640 & 76 & - & - & 1027 \\
\hline Bad Colberg & 18 & 0 & 322.5 & 224.5 & 555.5 & 157 & 123.5 & - & 1401 \\
\hline $\begin{array}{l}\text { Wolfersdorf } \\
\text { (Stockheim outcrop) }\end{array}$ & 14 & 0 & 0 & 0 & 0 & 0 & 726 & 29.5 & 769.5 \\
\hline
\end{tabular}

of deep, fault-bounded grabens, whereas the Rotliegend top is characterized by a peneplain beneath the Zechstein (Bader and Bram, 2001; Buness and Bram, 2001). This suggests a regional disconformity between Rotliegend and Zechstein and supports the separation between the CarboniferousPermian (mainly Rotliegend) Kraichgau Basin and the postRotliegend (mainly Mesozoic) Franconian Basin development (Freudenberger et al., 2006; Paul, 2006).

Triassic stratigraphy is divided into Lower to lowermost Middle Triassic Buntsandstein, Middle Triassic Muschelkalk, and uppermost Middle to Upper Triassic Keuper groups (STD, 2016; Fig. 2). Siliciclastic sandstones of the Buntsandstein Group are $572 \mathrm{~m}$ thick in the Staffelstein 1 well, $530.7 \mathrm{~m}$ in the Mürsbach 6 well, and $510 \mathrm{~m}$ in the Eltmann well, decreasing to $417.15 \mathrm{~m}$ in the Obernsees well in the southeast (Table 1, Gudden, 1977; Emmert et al., 1985; Helmkampf, 2006). Buntsandstein units are exposed in fault blocks between the FFS and the Eisfeld-Kulmbach Fault in the eastern part of the study area (Fig. 1). The Muschelkalk Group is dominated by carbonates, dolomites, and a small amount of gypsum and is $240 \mathrm{~m}$ thick in the Staffelstein 1 well, $210.7 \mathrm{~m}$ in the Mürsbach 6 well, and $236 \mathrm{~m}$ in the Eltmann well, decreasing southeastward to $178 \mathrm{~m}$ in the Obernsees well (Table 1, Gudden, 1977; Emmert et al., 1985). Muschelkalk units crop out along the FFS and the Eisfeld-Kulmbach Fault and also west of the Eltmann well (Fig. 1). The Keuper Group consists mainly of sandstones that are $530.2 \mathrm{~m}$ thick in the Staffelstein 1 well and $532 \mathrm{~m}$ in the Staffelstein 2 well, while decreasing southeastward to $483 \mathrm{~m}$ in the Obernsees well (Franz et al., 2014; Gudden, 1977; Emmert et al., 1985). Keuper units are broadly exposed in the western and northwestern part of the study area and in the fault block bounded by the Eisfeld-Kulmbach and Asslitz faults (Fig. 1). Jurassic units are preserved in the central and eastern parts of the study area but eroded towards the west and northwest (Fig. 1). Jurassic outcrops to the east are fault-bounded and are limited to the footwall of the Eisfeld-Kulmbach, Asslitz, and Lichtenfels reverse faults (Fig. 1). The Jurassic interval is 102 to $104 \mathrm{~m}$ thick in the Staffelstein 1 and 2 wells in the north and $140 \mathrm{~m}$ thick in the Obernsees well in the SE (Table 1; Meyer, 1985; Gudden, 1977). Cretaceous sedimentary rocks are preserved in the central and southeastern parts of the study area (Fig. 1).

The structural architecture of the eastern study area is characterized by NW-SE-striking multi-segmented reverse faults that are tens to hundreds of kilometers in length (e.g., Eisfeld-Kulmbach and Asslitz faults), whereas towards the west only normal faults (e.g., Bamberg Fault, KissingenHaßfurt fault zone) are developed (Fig. 1). The NW-SEstriking Franconian Fault System (FFS) is the dominant structural feature, representing the tectonic contact between the western Bohemian Massif to the east and the late Permian to Mesozoic Franconian Basin to the west (Fig. 1). The FFS most likely initiated during latest Variscan tectonics and was reactivated at least during Early Triassic and Cretaceous times (Carlé, 1955; von Freyberg, 1969; Peterek et al., 1997; Wagner et al., 1997). The total amount of hanging wall uplift on the FFS is estimated at ca. $5500 \mathrm{~m}$, as evidenced by titanite and apatite fission-track ages, the sericite K-Ar ages of fault rocks and the sedimentary strata adjacent to the fault (Wemmer, 1991; Wagner et al., 1997; Peterek et al., 1997). Sub-parallel to and ca. $9 \mathrm{~km} \mathrm{SW}$ of the FFS, the NE-dipping 


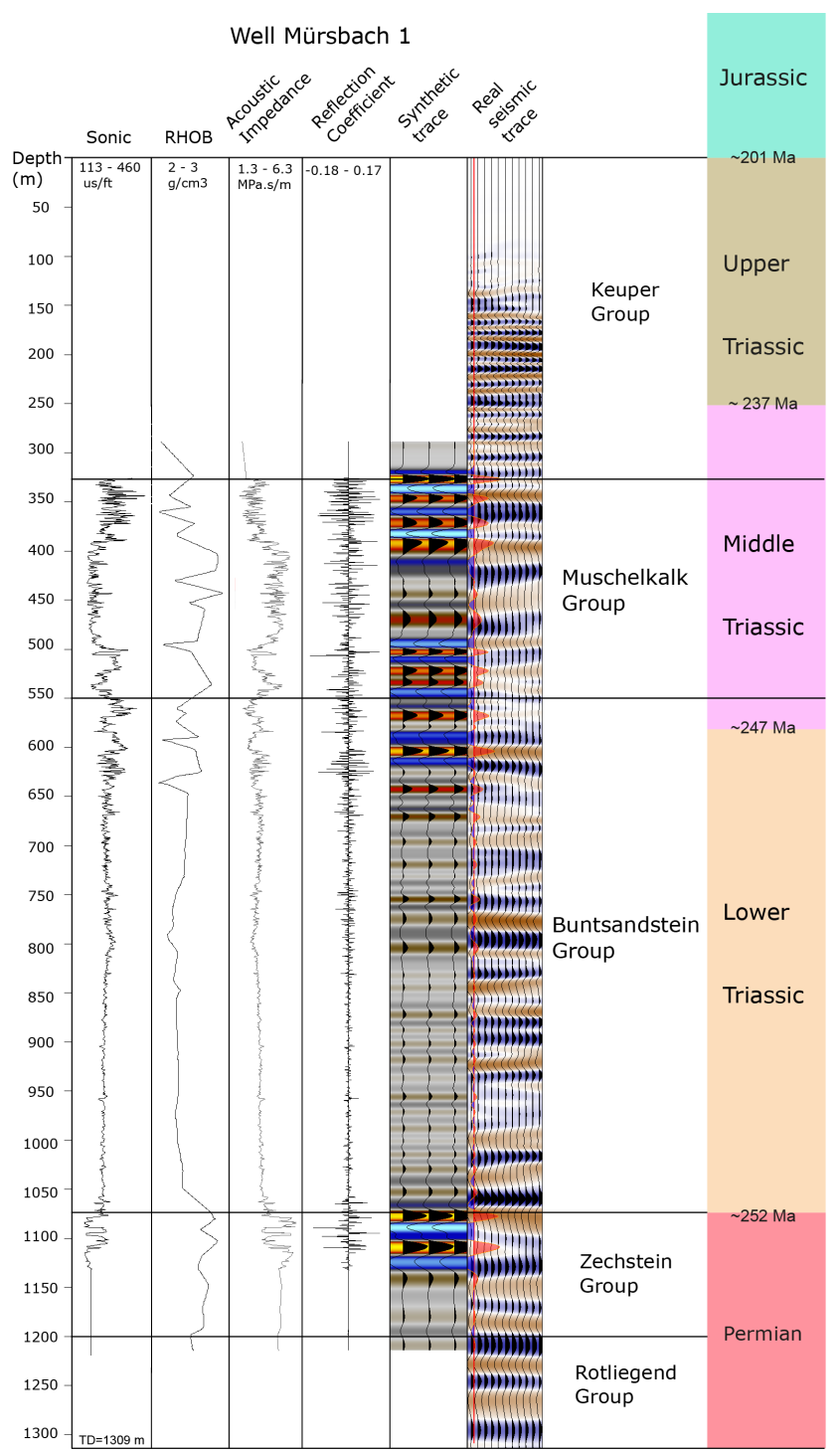

Figure 2. Velocity and density $\operatorname{logs}$ from the Mürsbach 1 well utilized for synthetic seismogram generation. Seismic traces from FRANKEN-1802 are compared with synthetically generated seismograms. Velocity data are used to construct time-depth relationships and well seismic ties. Depth to the formation tops are timeconverted and used as a starting point for seismic interpretation.

Eisfeld-Kulmbach Fault mainly exposes Lower and Middle Triassic units on its hanging wall side (Fig. 1). In the SE and the central footwall of the Eisfeld-Kulmbach Fault, Upper Triassic and Lower Jurassic units crop out, while laterally to the NW Lower and Middle Triassic and some Permian units (Schalkau outcrop) are exposed (Fig. 1). Farther SW in the footwall of Eisfeld-Kulmbach Fault, the Asslitz Fault can be traced over ca. $50 \mathrm{~km}$, exposing Upper Triassic units in its hanging wall (Fig. 1). The westernmost major reverse fault is the Lichtenfels Fault, mapped over ca. $16 \mathrm{~km}$ at the surface (Fig. 1).
West and southwest of the Lichtenfels Fault, the structural architecture of the study area is dominated by NW-SE normal faults such as the Staffelstein and Bamberg faults and the prominent Kissingen-Haßfurt fault zone (Fig. 1). Studies of regional upper-crustal paleostress patterns reveal multiple changes in stress field orientations since the Paleozoic comprising normal faulting and both extensional and compressional strike-slip faulting, implying multiple fault reactivation events (Peterek et al., 1996a, 1997; Bergerat and Geyssant, 1982; Coubal et al., 2015; Navabpour et al., 2017; Köhler et al., 2022).

\section{Data and methods}

\subsection{FRANKEN seismic reflection acquisition and recording parameters}

The FRANKEN 2D seismic survey comprises of four seismic lines with a total line length of $230.8 \mathrm{~km}$. The survey area is situated in northern Bavaria, SE Germany, covering an area of approximately $90 \mathrm{~km} \times 45 \mathrm{~km}$ (Fig. 1). The FRANKEN seismic survey was designed to cross deep wells and image the upper-crustal levels in northern Bavaria. Together with existing DEKORP, KTB, and OPFZ (Oberpfalz) seismic surveys it constitutes a grid of 2D seismic reflection profiles, crossing major structural elements. FRANKEN1801 and 1803 lines are striking NW-SE perpendicular to the FRANKEN-1802 and 1804 profiles (Fig. 1). Profile FRANKEN-1803 links to the DEKORP-3/MVE-90 profile in the NW and to the OPFZ-9301 profile towards the SE (Fig. 1). FRANKEN-1802 and 1804 strike NE-SW and are perpendicular to the major fault zones. Table 2 summarizes acquisition and processing parameters of the FRANKEN seismic survey.

\subsection{Seismic interpretation methods}

In this study we integrate information from nine deep wells $(1100-1600 \mathrm{~m})$ and surface geology to interpret the newly acquired FRANKEN seismic reflection survey in SE Germany. Available wells are mainly located in the central and western parts of the study area (Fig. 1 and Table 1). Seismic well tie and time-depth relationships are established using sonic velocity and density logs of the Mürsbach 1 well (Gudden, 1971). The calculated synthetic seismogram is correlated with the real seismic traces at the well location and enabled us to transfer geological and (in particular) stratigraphic information from the well to the intersected seismic profiles (Fig. 2). Horizon interpretation started from the profile FRANKEN-1802 at the Mürsbach-1 well location where the best seismic well tie has been established. Interpretation of stratigraphic markers was then extended from the profile FRANKEN-1802 to other intersecting profiles. In the sedimentary cover, seismo-stratigraphic facies and seismic characters are defined based on the lateral and vertical changes 
Table 2. Recording parameters of the FRANKEN seismic survey.

\begin{tabular}{ll}
\hline Recording parameters & \\
\hline Number of profiles & 4 \\
FRANKEN-1801 & $47900 \mathrm{~m}, \mathrm{NW}-\mathrm{SE}$ \\
FRANKEN-1802 & $47750 \mathrm{~m}, \mathrm{NE}-\mathrm{SW}$ \\
FRANKEN-1803 & $71800 \mathrm{~m}, \mathrm{NW}-\mathrm{SE}$ \\
FRANKEN-1804 & $63350 \mathrm{~m}, \mathrm{NE}-\mathrm{SW}$ \\
\hline Method & Vibroseis \\
\hline Number of channels & 2400 \\
Spread & Symmetrical split-spread with roll-in and roll-off \\
Active spread & $800 \mathrm{stations}(2400$ stations) full spread \\
\hline Source & \\
\hline P-wave source & Prakla-Seismos VVCA/E, 3 vibrators \\
Hydraulic peak force & $13500 \mathrm{da} \mathrm{N}$ \\
Source energy & $28000 \mathrm{lbs}(125 \mathrm{kN}$ nominal) \\
Weight & $17000 \mathrm{~kg}$ \\
Sweep length & $16000 \mathrm{~ms}$ \\
Sweep frequency range & $8-64 \mathrm{~Hz}$ \\
Sweeps per VP & 6 \\
Sweep period & $8-40 \mathrm{~s}$ \\
Vertical stacking & 2 to 4 \\
\hline Recording & \\
\hline Source point distance & $100 \mathrm{~m}$ \\
Receiver point distance & $12.5 \mathrm{~m}$ \\
Natural frequency & $10 \mathrm{~Hz}$ \\
Geophone type & Sercel DSU-3, three component MEMS \\
Recording instrument & Sercel $428 \mathrm{XL}$ \\
Recording length & $8000 \mathrm{~ms}$ \\
Sampling rate & $4 \mathrm{~ms}$ \\
Recording format & SEG-D, 8058 \\
\hline & \\
\hline & \\
\hline
\end{tabular}

in seismic amplitudes, reflectivity, and coherency. Observed formation tops in wells in combination with defined seismostratigraphic facies are used in the seismic horizon interpretation, especially where there is no well available. Below the sedimentary cover, three main seismic facies are identified and are used to characterize and interpret basement units.

\subsection{Seismo-stratigraphic facies}

Characteristic seismic signatures of stratigraphic intervals drilled by wells and observed in the FRANKEN survey are first described for the Permo-Mesozoic interval. Upper Mesozoic-Cretaceous units are only locally preserved in the study area and are not drilled by any of the deep wells, restricting the interpretation of the Jurassic-Cretaceous boundary and the description of their seismic signature. Jurassic strata show a medium amplitude and semi-continuous reflections (Fig. 3a). The Triassic-Jurassic boundary is marked by the appearance of slightly higher amplitudes and rather continuous reflections in the Triassic compared to the overlying Jurassic interval (Fig. 3a). This boundary is correlated with the Staffelstein and Obernsees wells along profiles FRANKEN-1802 and 1803, respectively.

Upper Triassic Keuper units generally show continuous and medium- to high-amplitude reflections of alternating sandstones, siltstones, and some gypsiferous units (Fig. 3b). Only the shallow marine dolomites (Grabfeld Formation) at the base of the Keuper Group (Haunschild, 1985; Gudden, 1981) are characterized by high amplitudes and continuous pairs of reflections acting as regional marker reflection along all profiles (Fig. 3b). Middle Triassic Muschelkalk units are comprised of limestones, marlstones, and dolostones that are recorded by two distinct seismic facies in the study area: (1) a semi-continuous and medium-amplitude reflection with ca. $50 \mathrm{~ms}$ (two-way travel time, TWT) thickness on top and (2) continuous and high-amplitude reflections at the bottom (Fig. 3c). The sandstone-dominated Buntsandstein Group is characterized by semi-continuous and medium-energy amplitudes that show gradually increasing energy and continuity towards the top (Fig. 3d). A continuous and very high amplitude reflection defines the Permian-Triassic boundary between the Buntsandstein and the underlying Zechstein Group (Fig. 3d). The latter shows ca. 25-30 ms (TWT) of continuous and high-amplitude reflections, which are correlated to an anhydrite- and dolomite-bearing interval in the upper part of the Zechstein (Gudden, 1977; Schuh, 1985; Gudden and Schmid, 1985). Below the Zechstein high-amplitude reflections, semi-continuous and medium-amplitude reflections of the Rotliegend occur (Fig. 3e). These reflections represent the upper parts of the Rotliegend and gradually become less distinct and discontinuous with depth, with some reflections being only locally present and laterally becoming less pronounced to partly transparent (Figs. 3e, 4a and b). The boundary between the sedimentary cover and the underlying pre-Permian low- to medium-grade metasedimentary rocks (hereafter considered basement rocks) is drilled by the Wolfersdorf and Mittelberg wells in the north, the Eltmann well to the west, and the Obernsees well to the southeast and is not particularly reflective in the seismic survey (Table 1 and Fig. 4a and b). However, at some locations semicontinuous and low-energy reflections of the Rotliegend can be distinguished from discontinuous but slightly higher energy reflections below. When identified, such changes in reflection patterns are interpreted as the boundary between sedimentary cover and underlying metasedimentary rocks (Fig. 4a and b).

\subsection{Basement seismic facies}

Basement units below the sedimentary cover comprise three seismic facies based on differences in reflectivity, frequency, and continuity of reflections.

\subsubsection{Basement seismic facies 1 (BSF1)}

Basement seismic facies 1 (BSF1) consists of discontinuous, low-amplitude, and low-frequency reflections that become transparent at some locations (Fig. $4 \mathrm{a}$ and b). Higheramplitude and semi-continuous reflections of the Rotliegend progressively grade into BSF1 without a seismically de- 

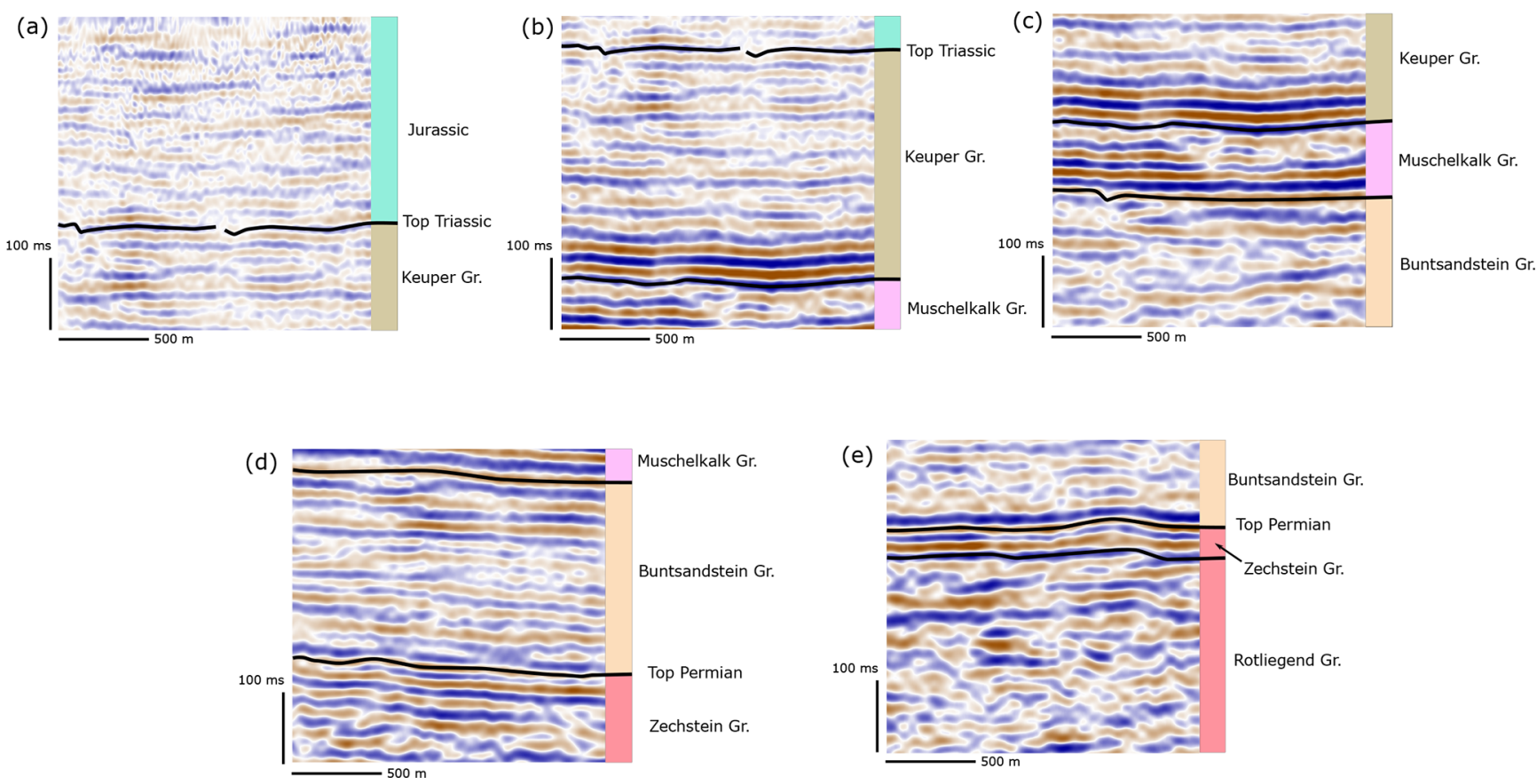

Figure 3. Seismo-stratigraphic facies of observed Permian-Jurassic stratigraphy in the study area: (a) Jurassic, (b) Upper Triassic Keuper Group, (c) Middle Triassic Muschelkalk Group, (d) Lower Triassic Buntsandstein Group, and (d) Permian Zechstein and Rotliegend groups.

tectable boundary (Fig. 4b). The thicknesses of BSF1 units generally decrease westward and reach $2.5 \mathrm{~s}$ TWT at their deepest position. BSF1 is sampled by the Eltmann well, where $94 \mathrm{~m}$ of (?Devonian) quartzites and metasedimentary rocks are described (Trusheim, 1964), whereas the Obernsees well cored $48.3 \mathrm{~m}$ of ?Late Paleozoic metasedimentary rocks (Table 1, Stettner and Salger, 1985). Farther north Mittelberg well drilled into $100.5 \mathrm{~m}$ of Upper Devonian-lower Carboniferous rocks below the Rotliegend (Table 1, (Friedlein and Hahn, 2018; Hahn et al., 2010). These Upper DevonianLower Carboniferous rocks (Gleitsch Formation) are interpreted as syn-Variscan inner shelf facies sedimentary rocks (Thuringian facies), low-grade metamorphosed during the Variscan orogeny (Hahn et al., 2010; Kroner et al., 2007). Although the Mittelberg well is not tied to seismic profiles, it additionally confirms the presence of low-grade metasedimentary rocks below the Rotliegend.

In the FFS's hanging wall, Münchberg Nappe units (Variscan allochthon) are transected by the DEKORP854N and DEKORP-3/MVE-90 seismic profiles (Figs. 1 and 5, Hirschmann, 1996; Heinrichs et al., 1994). Münchberg Nappe units are surrounded by low-grade metasedimentary rocks of outer shelf facies (Bavarian facies) and inner shelf facies (Thuringian facies; von Gümbel, 1879; Linnemann et al., 2010; Heuse et al., 2010). Exposed nappe units and lowgrade metasedimentary rocks show discontinuous to semicontinuous and low-amplitude reflections, similar to BSF1 of the FRANKEN survey in the FFS footwall (Fig. 5). Similar low-amplitude and low-frequency reflections of BSF1 are also observed at the NW end of the DEKORP85-4N profile (Fig. 5a and b). There, these reflections are associated with low-grade Lower Carboniferous flysch deposits (inner and outer shelf facies) exposed at the surface (DEKORP Research Group, 1994a). Based on seismic facies description and in the absence of well information, differentiation between allochthons, flysch sedimentary rocks, and inner and outer shelf facies is ambiguous. BSF1 is therefore interpreted as the western to southwestern extension of low-grade inner and outer shelf facies, low-grade Lower Carboniferous flysch sedimentary rocks, and possible Variscan allochthons (DEKORP Research Group, 1994b). Correlating with exposed basement units E-NE of the FFS, these units are interpreted to represent the W-SW extension of the ZiegenrückTeuschnitz syncline of the Saxothuringian zone.

\subsubsection{Basement seismic facies 2 (BSF2)}

High-amplitude, continuous, and dipping reflection packages are bounding BSF1 at depth and are defined as basement seismic facies 2 (BSF2, Figs. 4a, c and 5). BSF2 reflections are not drilled by wells within the survey area. However, similar reflections observed along reprocessed DEKORP85-4N and DEKORP-3/MVE-90 profiles below BSF1 can be correlated with exposures of highly sheared rocks including phyllites developed during Variscan tectonics (Fig. 5; DEKORP and Orogenic Processes Working Group, 1999; Franke and Stein, 2000). We interpret BSF2 as Variscan detachment and shear zones translating and involving low-grade inner and outer 

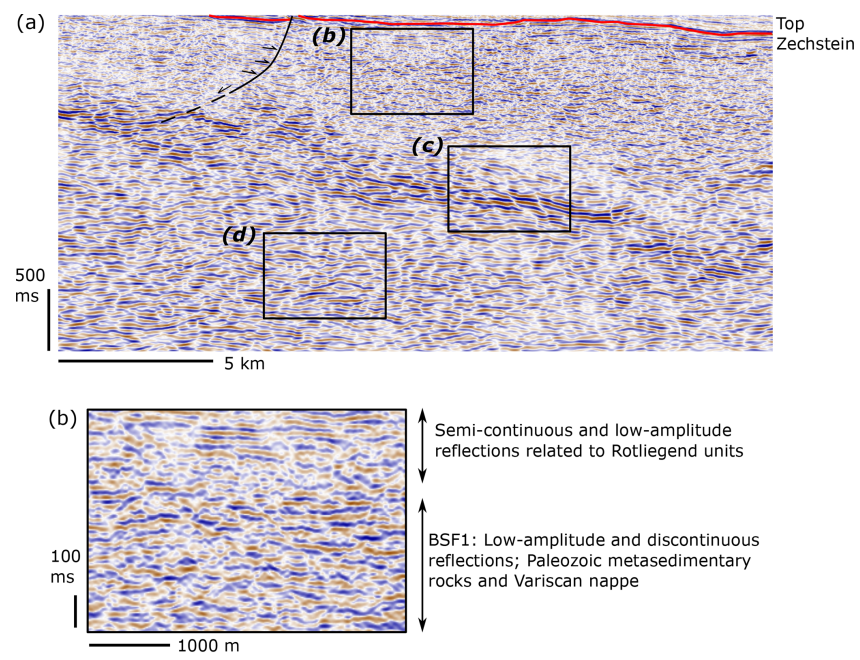

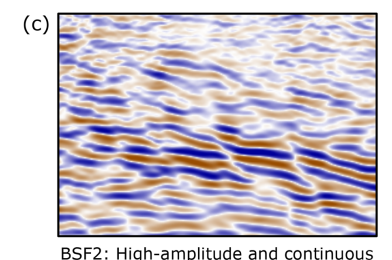

BSF2: High-amplitude and continuous reflections; Variscan shear zone

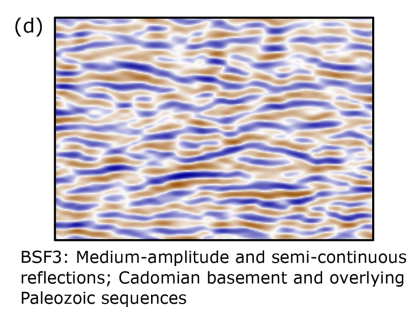

Figure 4. Basement seismic facies (BSF) described along the FRANKEN seismic survey. Panel (a) shows the SE portion of FRANKEN-1804 below the Top Zechstein horizon. (b) Lowamplitude and discontinuous reflections of BSF1 interpreted as Paleozoic metasedimentary rocks and Variscan nappe units. (c) BSF2 shows high-amplitude, continuous, and dipping reflections interpreted as Variscan shear zones. (d) Medium-amplitude and semicontinuous reflections of BSF3 below the Variscan shear zone related to the Cadomian basement and Paleozoic inner shelf facies not involved in Variscan tectonics.

shelf facies, low-grade Lower Carboniferous flysch sedimentary rocks, and Variscan nappes. BSF2 therefore includes the upper parts of the Saxothuringian parautochthons (highly sheared parts of inner shelf facies) and lower parts of allochthons. Similar intra-basement, high-amplitude and dipping reflections are interpreted as orogenic and post-orogenic shear zones in the Norwegian Caledonides (Phillips et al., 2016; Fazlikhani et al., 2017; Wrona et al., 2020; Osagiede et al., 2019), offshore of Brazil (Strugale et al., 2021; Vasconcelos et al., 2019), offshore of New Zealand (Collanega et al., 2019; Phillips and McCaffrey, 2019), and in the South China Sea (Ye et al., 2020). High-amplitude and continuous reflections of BSF2 below the Münchberg Nappe and across the FFS to the west are therefore interpreted as the W-SW extension of a Variscan detachment and shear zone transporting allochthonous nappes and underlying metasedimentary rocks W-SW towards the Franconian Basin area. BSF2 reflections generally get shallower from east to west and reach the base of the overlying sedimentary units.

\subsubsection{Basement seismic facies 3 (BSF3)}

Basement seismic facies 3 (BSF3) is characterized by semicontinuous and medium-amplitude reflections (Fig. 4a and d). BSF3 is bounded by BSF2 at the top and extends to the lower limit of the dataset at $8 \mathrm{~s}$ TWT. BSF3 does not show any preferential dip direction and locally hosts some higheramplitude, continuous, and dipping reflections of BSF2. Such high-amplitude reflections of BSF2 are branching off the main BSF2 packages or are developed at deeper levels and are interpreted as segments of major shear zones or locally developed shear zones of Variscan origin. BSF3 is not drilled by wells, nevertheless considering the tectonostratigraphic position of BSF3 below the Variscan detachment/shear zones (BSF2), BSF3 is interpreted to represent Cadomian basement rocks and overlying Paleozoic inner shelf facies not involved in Variscan tectonics.

\section{Seismic reflection interpretation of the FRANKEN seismic survey}

Described seismic facies in the sedimentary cover and underlying basement units and well information are utilized in this chapter to interpret the FRANKEN seismic profiles.

\subsection{Profile FRANKEN-1801}

Profile FRANKEN-1801 is $47.9 \mathrm{~km}$ long and extends NWSE from south of Bamberg to the NW of Haßfurt (Fig. 1). At the surface, mainly Keuper units are exposed (Fig. 1). Thicknesses of remnant Keuper units progressively decrease to the W-NW, and at the northwestern edge of profile FRANKEN1801 Muschelkalk units are exposed at the surface in the footwall of a segment of the Kissingen-Haßfurt Fault zone (Fig. 6). This fault zone is mapped over ca. $60 \mathrm{~km}$ with ca. $7-10 \mathrm{~km}$ width and is sub-parallel to the NW-SE-striking FRANKEN-1801 profile (Fig. 1). Some segments of the Kissingen-Haßfurt Fault zone are oblique and are imaged by the FRANKEN-1801 profile. Muschelkalk and Buntsandstein units are fairly tabular with no major lateral thickness changes (Fig. 6). Most of the interpreted faults (seismic scale) are normal faults, while major reverse faults are sub-parallel to the profile and are not imaged in FRANKEN1801.

Below the Buntsandstein, Permian deposits including $114 \mathrm{~m}$ Zechstein and $3 \mathrm{~m}$ Rotliegend have been drilled by the Eltmann well, $2230 \mathrm{~m}$ to the NE of profile FRANKEN-1801 (Fig. 6) (Trusheim, 1964). Semi-continuous and mediumamplitude reflections below the Zechstein are interpreted as Rotliegend deposits (Fig. 6). As the Rotliegend base is not particularly reflective in the seismic reflection data, it is difficult to interpret the top basement. Towards the NW in the center of the FRANKEN-1801 profile, BSF1 reflections (Paleozoic metasedimentary rocks and Variscan nappes) are present below the Permian rocks and are under- 

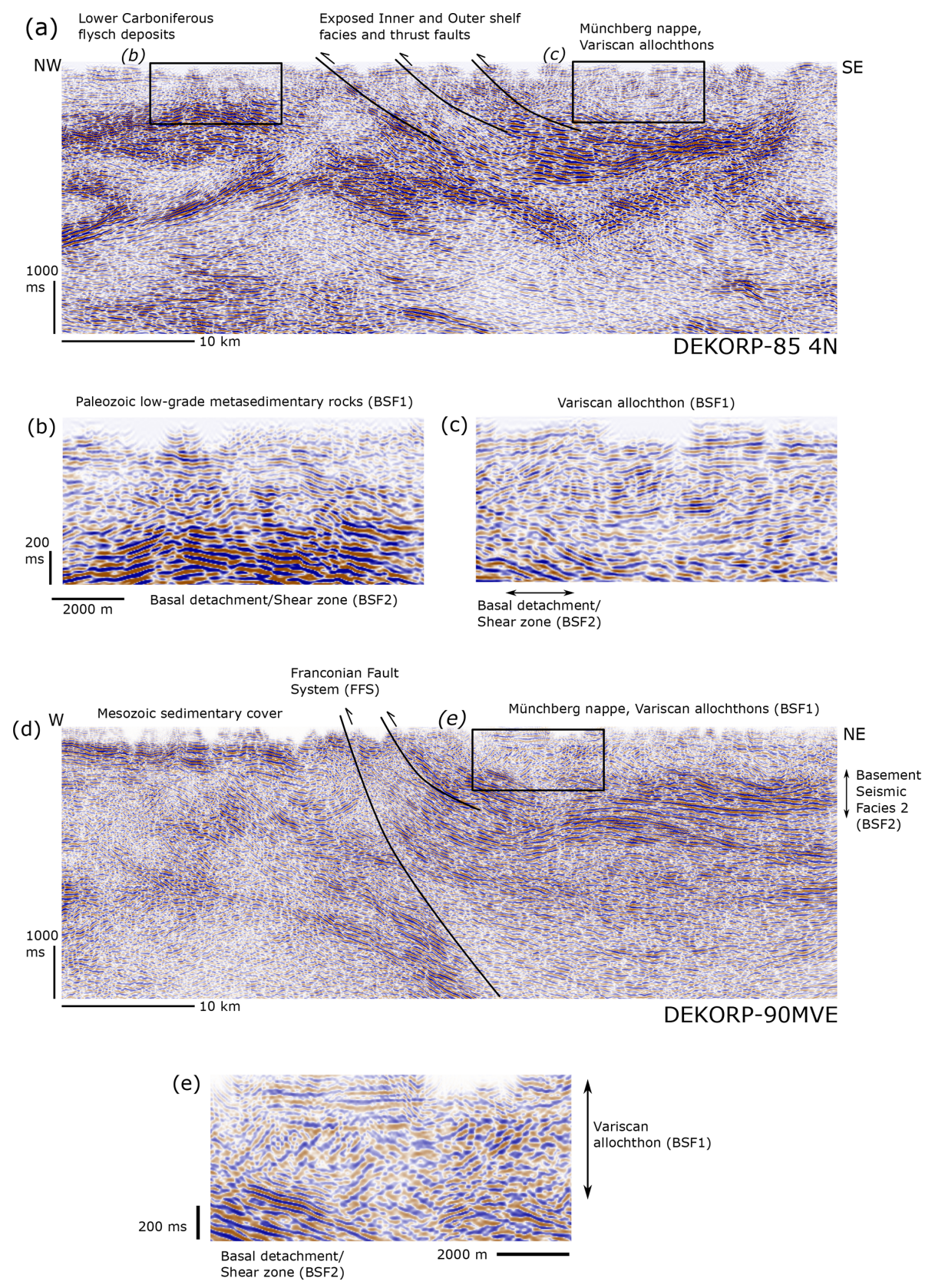

Figure 5. Reprocessed DEKORP-85 4N and DEKORP-3/MVE-90 profiles used to compare three basement seismic facies (BSF1-3) described along the FRANKEN seismic survey (see Fig. 1 for locations). DEKORP profiles image exposed Variscan units along the western Bohemian Massif and are used as proxy for geological interpretation of BSFs. (a) DEKORP-85 4N shows the seismic signature of Paleozoic low-grade metasedimentary rocks (zoomed in b) and Münchberg Nappe (Variscan allochthon, zoomed in c) exposed at the surface and described as BSF1. (d) DEKORP-3/MVE-90 images of Münchberg Nappe units to the east and Permian-Jurassic sedimentary cover to the west of Franconian Fault System (FFS). Panel (e) shows the seismic signature of Variscan nappes (BSF1) and underlying shear zones (BSF2).

lain by a Variscan shear zone (BSF2, Fig. 6). From the SE, the Variscan shear zone shallows to the NW and reaches ca. $700 \mathrm{~ms}$ TWT at the center of the profile (Fig. 6).

\subsection{Profile FRANKEN-1802}

Profile FRANKEN-1802 extends NE-SW with $47.7 \mathrm{~km}$ length (Fig. 1). This profile is at a high angle to the prominent NW-SE faults and therefore provides a good subsurface image of these structures (Fig. 7). Profile FRANKEN1802 is tied to the Eltmann well and runs close to the 


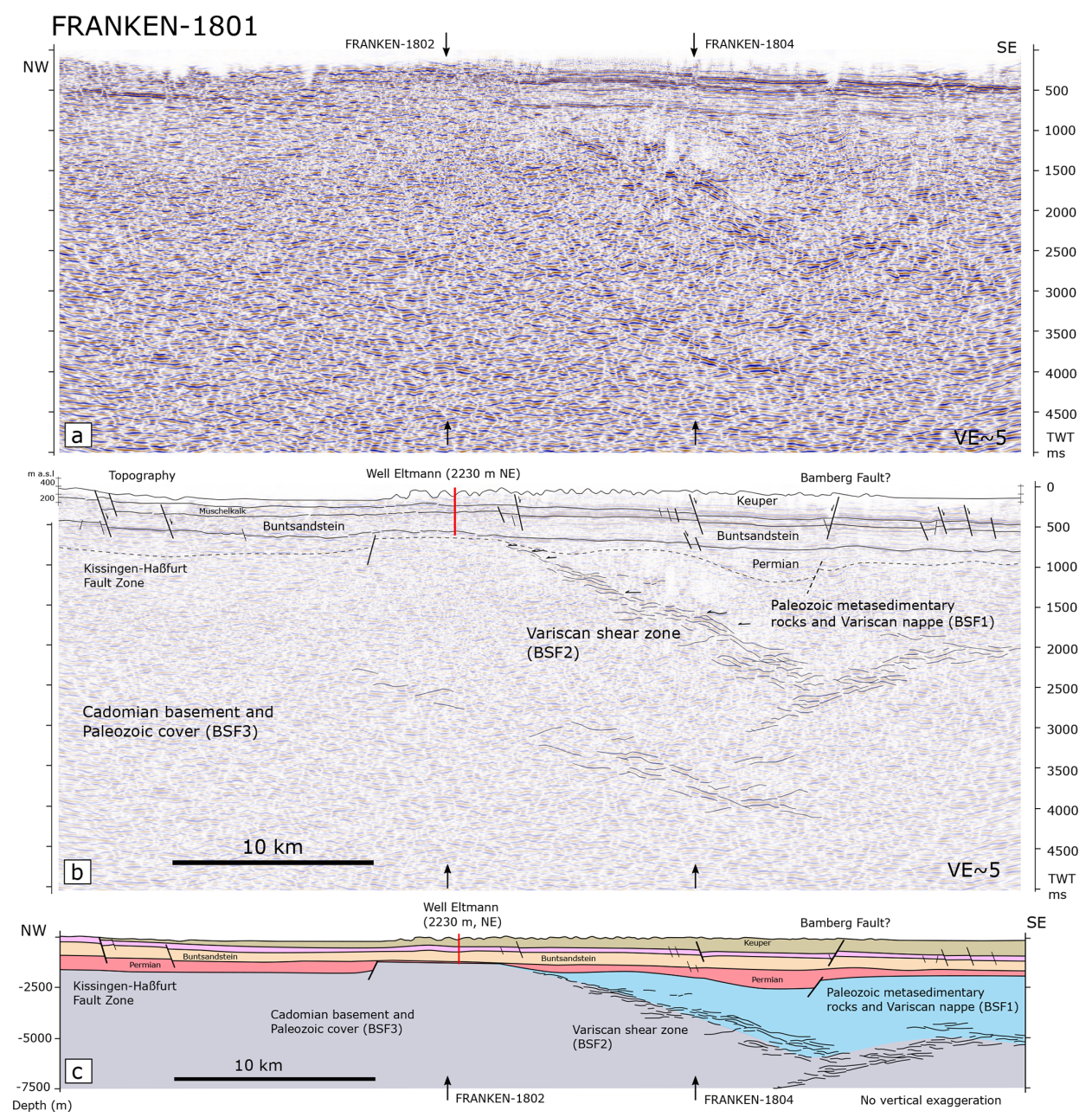

Figure 6. (a) Uninterpreted and (b) interpreted FRANKEN-1801 profile. Horizon interpretation is tied to drilled wells in the study area. (c) Depth-converted profile with no vertical exaggeration. Intersecting profiles FRANKEN 1802 and 1804 are shown by black arrows. See Fig. 1 for the profile location.

Mürsbach 6 (630 m to the S), Staffelstein 1 (1235 m, to the SE), and Staffelstein 2 wells ( $890 \mathrm{~m}$, to the SE). Profile FRANKEN-1802 is used as the reference profile for the seismo-stratigraphic interpretation (Fig. 7). Jurassic rocks are preserved in the footwall of the Mürsbach and Lichtenfels reverse faults drilled with $104 \mathrm{~m}$ thickness by well Staffelstein 2 (Table 1; Gudden, 1977). Keuper strata are exposed in the hanging wall of the Lichtenfels Fault at the northeastern edge of profile FRANKEN-1802 (Fig. 7). Keuper is drilled with $532 \mathrm{~m}$ in thickness by the Staffelstein 2 well. Towards the SW the Keuper is increasingly eroded, and only $178.6 \mathrm{~m}$ are preserved at the location of the Eltmann well (Fig. 7 and Table 1, Gudden, 1977; Trusheim, 1964). Muschelkalk and Buntsandstein sedimentary rocks are tabular and regionally dip to the E-NE (Fig. 7). The Zechstein is penetrated by the Eltmann, Mürsbach 1 and 6, and Staffelstein 1 wells and is 103-121 m thick (Table 1; Gudden, 1985). Below the Zechstein units, Rotliegend is drilled by the Eltmann, Mürsbach 1 and 6, and Staffelstein 1 wells without reaching the underlying basement, except in the Eltmann well (Table 1). Mediumamplitude and semi-continuous reflections, characteristic of the Rotliegend in the study area, are also locally observed, suggesting the presence of Rotliegend laterally away from wells (Fig. 7). Rotliegend units are wedge shaped and are tilted to the E-NE, onlapping to deep-sited W-SW-dipping normal faults in the footwall of the Mürsbach and Lichtenfels reverse faults (Fig. 7). Interpreted W-SW-dipping normal faults appear to be crosscut by the oppositely dipping (ENE) Lichtenfels and Mürsbach reverse faults in Buntsandstein units (Fig. 7). E-NE block rotation in the hanging wall of these normal faults created local half-grabens observed exclusively in the Rotliegend section (Fig. 7). In the hanging wall of a normal fault located in the footwall of Lichtenfels Fault, the thickness of the Permian section is $>330 \mathrm{~ms}$ TWT (ca. $640 \mathrm{~m}$ ) that thins W-SW to ca. $120 \mathrm{~ms}$ TWT (ca. $240 \mathrm{~m}$ ) in the hanging wall of the Mürsbach Fault (Fig. 7). The in- 
terpretation of lateral thickness changes in the Permian is in good accordance with $142.3 \mathrm{~m}$ minimum thickness of Permian drilled in the Mürsbach 6 well (Table 1). The thickness of the Permian section in the hanging wall of Bamberg Fault is $>200 \mathrm{~ms}$ TWT (ca. $390 \mathrm{~m}$ ), decreasing to the W-SW down to the $3 \mathrm{~m}$ drilled at the Eltmann well (Fig. 7).

Sedimentary units in the hanging wall of the Lichtenfels Fault are uplifted and gently folded where the entire Jurassic and the upper parts of the Upper Triassic Keuper Group are eroded (Fig. 7). In the footwall of the Lichtenfels Fault, sedimentary units are folded by a normal drag fold, creating a local synformal structure (also known as the Hollfeld syncline) where Jurassic rocks are preserved (Fig. 7). The NWSE-striking Lichtenfels Fault is laterally and vertically segmented and is exposed at the surface over ca. $16 \mathrm{~km}$ length (Fig. 1). In profile FRANKEN-1802, the Lichtenfels Fault has $135 \mathrm{~ms}$ TWT (ca. $260 \mathrm{~m}$ ) throw when measured at the top of the Buntsandstein (Fig. 7). The Mürsbach Fault strikes NNW-SSE over ca. $5 \mathrm{~km}$ and has been imaged by the Mürsbach seismic survey along three short $(<4 \mathrm{~km}) 2 \mathrm{D}$ seismic sections (Flemm et al., unpublished data). The Mürsbach Fault shows ca. $65 \mathrm{~ms}$ TWT (ca. $120 \mathrm{~m}$ ) throw measured at the Buntsandstein top. Both the Muschelkalk and Keuper units are folded, creating a local anticline in the hanging wall of the Mürsbach Fault. Upper parts of the Keuper and younger units are both eroded on the hanging wall side, while in the immediate footwall some of the Jurassic units are still preserved (Fig. 7). E-NE-dipping normal faults interpreted in the SW part of the profile FRANKEN-1802 are subparallel to the SE extension of the Kissingen-Haßfurt Fault Zone (Fig. 7).

In the Eltmann well, $94 \mathrm{~m}$ of ?Devonian metasedimentary rocks are drilled below the sedimentary cover and correlated with BSF1 (Fig. 7; Trusheim, 1964). Identified BSF1 units are ca. $800 \mathrm{~ms}$ TWT (ca. $1560 \mathrm{~m}$ ) thick in the NE of the seismic section, decreasing to $94 \mathrm{~m}$ towards the SW at the location of well Eltmann. BSF2 reflections show a concave up geometry below the Lichtenfels and Mürsbach faults and extend to shallower depth towards the west (Fig. 7). In the center of the profile some high-amplitude reflections of BSF2 branch off from the main reflection package and extend into the deeper parts of the crust (Fig. 7).

\subsection{Profile FRANKEN-1803}

This profile is subparallel to the profile FRANKEN-1801 and strikes NW-SE over $71.8 \mathrm{~km}$ length (Fig. 1). The Obernsees well is located $945 \mathrm{~m} \mathrm{SW}$ of this profile and drilled into $140 \mathrm{~m}$ of Jurassic units, the entire Triassic succession, and $104.9 \mathrm{~m}$ of upper Permian Zechstein units (Table 1 and Fig. 8, Helmkampf, 2006). Jurassic units are preserved at the surface, except in the SE and NW parts of profile 1803, indicating a gentle synformal geometry, with remnant Jurassic units being thickest in the center of the profile (Fig. 8). Triassic intervals show subparallel boundaries with only mi- nor lateral thickness changes. At the Obernsees well, the Rotliegend is only $18.3 \mathrm{~m}$ thick overlying metasedimentary rocks of possible Late Paleozoic age (Stettner and Salger, 1985; Ravidà et al., 2021). The reduced thickness of Rotliegend units in the Obernsees well is related to a local basement high in the footwall of an ESE-dipping normal fault (Fig. 8). In the hanging wall of this normal fault and to the SE, medium-amplitude and semi-continuous reflections below the top Zechstein horizon are interpreted as Rotliegend (Fig. 8, Stettner and Salger, 1985; Schuh, 1985). Permian units are underlain by Paleozoic metasedimentary rocks and Variscan nappes (BSF1 units, Fig. 8). BSF2 reflections are sub-horizontal (between 2000-2500 ms, TWT) and gradually get shallower to the NW to reach to ca. $1200 \mathrm{~ms}$ TWT. From the SE to the center of the profile, BSF2 reflections become less pronounced and appear to be segmented into a steeper and a sub-horizontal segment (Fig. 8). Farther NW, BSF2 reflections reach to a shallower depth and are also imaged by the perpendicular FRANKEN-1802 and 1804 profiles. Lateral segmentation and changes in the reflectivity of the BSF2 might be related to the 3D geometry of an interpreted detachment or shear zone (Fig. 8).

\subsection{Profile FRANKEN-1804}

This profile strikes NE-SW over $63.3 \mathrm{~km}$ and is subparallel to the profile FRANKEN-1802 (Fig. 9). Jurassic units are preserved in the NE and the central part of the profile. However, to the SW Jurassic units are eroded and Keuper sandstones are exposed at the surface (Fig. 9). Geometries of Triassic units are fairly tabular, generally with shallow dips to the NE-E but with variable dip angles between fault blocks. High-amplitude and continuous reflections below the Triassic units are interpreted as Zechstein and are correlated with similar reflection packages in perpendicular profiles FRANKEN-1801 and 1803. Semi-continuous and medium-amplitude reflections beneath the Zechstein are interpreted as Rotliegend that locally overlaps with the hanging wall of deep-seated W-to-SW-dipping normal faults (Fig. 9). In general, Permian units are wedge shaped in the hanging walls of normal faults and laterally thin. Paleozoic metasedimentary units and Variscan nappes (BSF1) underlie the Permian and are ca. $1400 \mathrm{~ms}$ TWT (ca. $2700 \mathrm{~m}$ ) thick in the center of the profile but laterally thin. The Variscan shear zone (BSF2) underlying Paleozoic metasedimentary units and Variscan nappes are concave-shaped in the NE and reach to shallower depths toward the southwestern edge of the profile FRANKEN-1804 (Fig. 9). In the center of the profile, BSF2 reflections are observed at greater depth up to about $3000 \mathrm{~ms}$ TWT and are slightly less reflective. The Cadomian basement and parts of inner shelf facies not involved in Variscan tectonics (BSF3) characterize the deeper parts of the profile FRANKEN-1804 (Fig. 9).

At the NE edge of the profile FRANKEN-1804, the Eisfeld-Kulmbach Fault accumulates ca. $660 \mathrm{~ms}$ TWT (ca. 


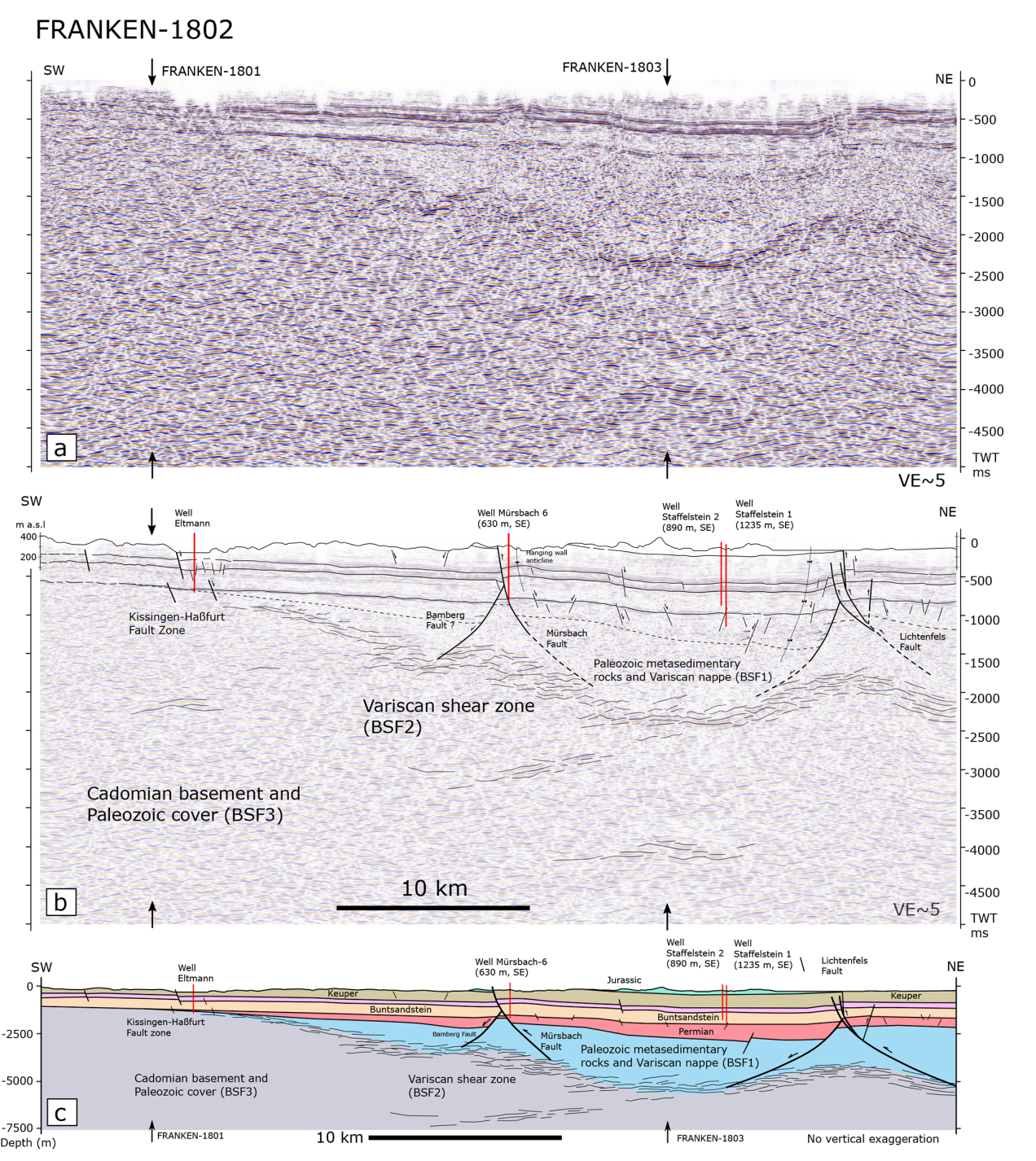

Figure 7. The FRANKEN-1802 profile strikes NE-SW, perpendicular to the main structures. (a) Uninterpreted and (b) interpreted seismic profile. FRANKEN-1802 is tied to the Eltmann, Mürsbach, and Staffelstein 1 and 2 wells. High-amplitude and continuous reflection of BSF2 interpreted as Variscan shear zones are at 2000-2500 ms TWT (5-6.5 km) in the NE and reach to the base of Permian sedimentary rocks to the SE. Vertical exaggeration is $5 \times$. (c) Depth-converted section with no vertical exaggeration. See Fig. 1 for the profile location.

$1280 \mathrm{~m}$ ) of throw, exposing Buntsandstein in its hanging wall (Fig. 9). Across the fault, Jurassic units are preserved in the footwall and are thin towards the SW, where they are eroded in the hanging wall of the Asslitz Fault (Fig. 9). The Asslitz Fault accumulates ca. $210 \mathrm{~ms}$ TWT (ca. $420 \mathrm{~m}$ ) of throw at the top of the Buntsandstein. Farther SW, the Lichtenfels Fault offsets Permian to Upper Triassic units with ca. $90 \mathrm{~ms}$ TWT (ca. $170 \mathrm{~m}$ ) of throw measured at the Muschelkalk top. In contrast to profile FRANKEN-1802 (ca. $9 \mathrm{~km} \mathrm{NW}$ ), along the FRANKEN-1804 profile the Lichtenfels Fault does not reach to the surface and dies out within the Keuper units. In the footwall of Lichtenfels Fault, a W-to-SW-dipping normal fault creates a local half-graben where continuous and medium-amplitude reflections are onlapping and terminating against the fault (Fig. 9). Further to the SW, Bamberg
Fault is a major normal fault displacing the Triassic and Permian units with ca. $40 \mathrm{~ms}$ TWT (ca. $80 \mathrm{~m}$ ) offset measured at top Muschelkalk. Bamberg Fault detaches into the underlying Variscan shear zone (BSF2) at depth (Fig. 9). Farther north along the FRANKEN-1802 profile, Bamberg fault is displaced by the Mürsbach reverse fault (Fig. 7).

\section{Discussion}

\subsection{Westward extension of the Saxothuringian zone}

Exposed Variscan allochthons are tectonically placed above the Paleozoic outer shelf facies (Bavarian facies), which are defined as fine-grained and clay-rich material preserved 
FRANKEN-1803

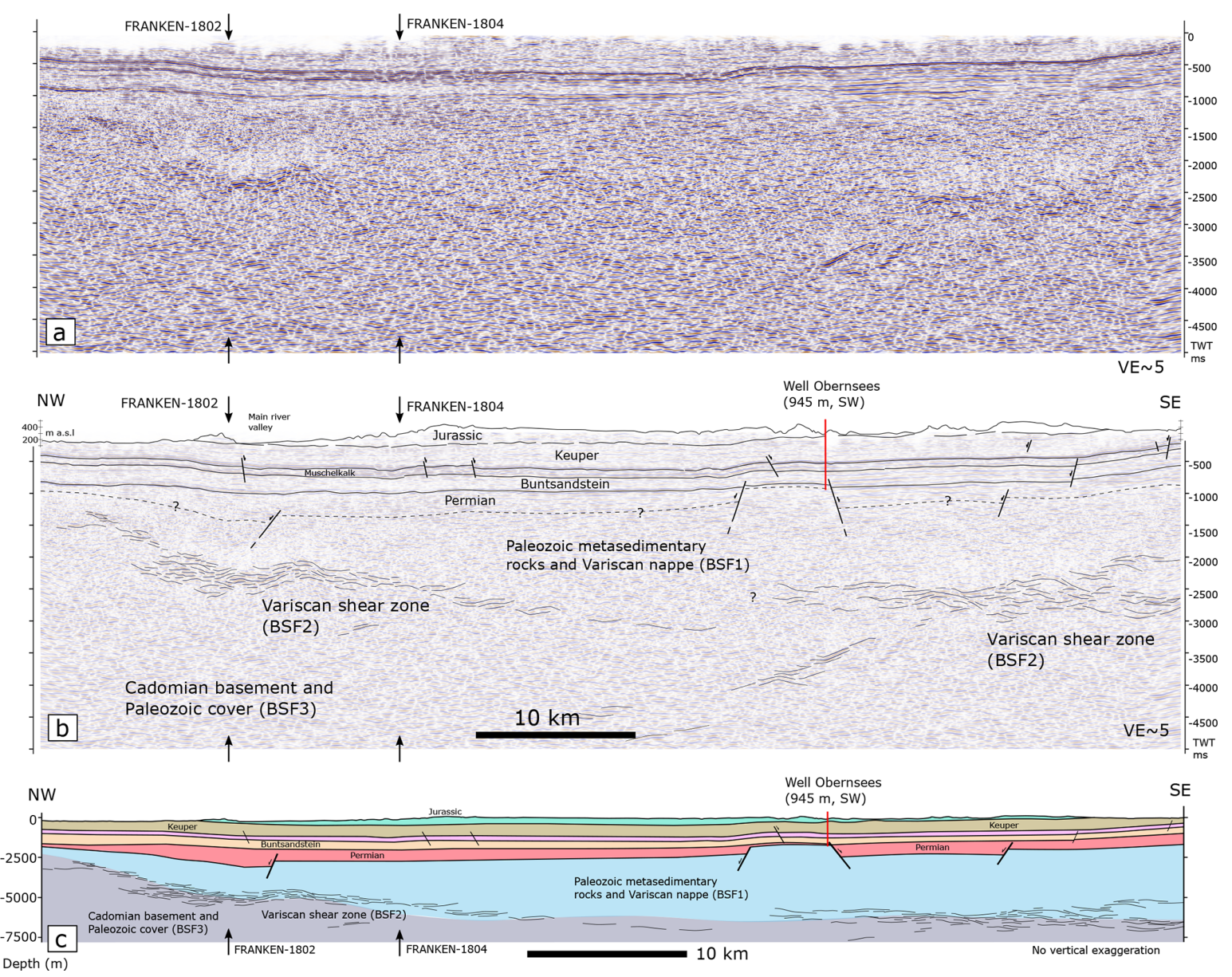

Figure 8. The SE-NW-striking FRANKEN-1803 profile, sub-parallel to the FRANKEN-1801 profile. Horizon interpretation is tied to the Obernsees well and the intersection of the FRANKEN 1801 and 1804 profiles. (a) Uninterpreted and (b) interpreted profile. (c) A depthconverted section with no vertical exaggeration. Interpreted Variscan shear zones (BSF2) are at 2000-3000 ms (5-7 km) in the SE and reach to ca. $2.5 \mathrm{~km}$ depth toward the NW.

around and below Variscan nappe piles (Linnemann and Heuse, 2001; Franke and Stein, 2000). BSF1 units observed beneath the sedimentary cover west of the FFS (Figs. 7 and 9) are interpreted as equivalents of Paleozoic metasedimentary rocks and Variscan nappe units (e.g., Münchberg Nappe, Fig. 10). BSF1 units are mapped as far as ca. $65 \mathrm{~km}$ west of the FFS and thin towards the NW along the NW-SE-striking profiles (Figs. 6 and 8) and towards the SW along the NESW-striking profiles (Figs. 7 and 9), showing a general westward thinning of Variscan nappes and Paleozoic metasedimentary rocks. Wells drilled in the Schwarzwald and Upper Rhein Graben areas (ca. $300 \mathrm{~km} \mathrm{SW}$ of the study area) show low-grade metasedimentary units (shales and phyllites) and volcanic rocks below sedimentary cover, interpreted as SW extension of the Saxothuringian Zone (Franke et al., 2017). Although seismic reflection and a few well data confirm the presence of low-grade to very low-grade metasedimentary rocks below the Permian to Jurassic sedimentary cover in the study area, no well has probed the Variscan nappes west of the FFS yet. Seismic signatures of exposed Variscan nappes and low-grade metasedimentary rocks east of the FFS do not allow differentiation between nappes and metasedimentary rocks. Similar observations have been made in the Caledonides of western Norway (Fazlikhani et al., 2017; Lenhart et al., 2019). Differentiation of Paleozoic inner and outer shelf facies is also beyond the resolution of available seismic reflection data. However, the tectonostratigraphic position of Variscan nappes and metasedimentary rocks relative to basal shear zones in exposed basement units east of the FFS (Heuse et al., 2010; Linnemann et al., 2010) supports the possible presence of Variscan nappes and underlying inner and outer shelf facies ca. $65 \mathrm{~km}$ west of FFS (Fig. 10).

In the exposed parts of the Saxothuringian zone east of FFS, kinematic indicators show a top to W-SW tectonic transport under NE-SW compression (Schwan, 1974). This deformation phase has been described as "D1" deformation 


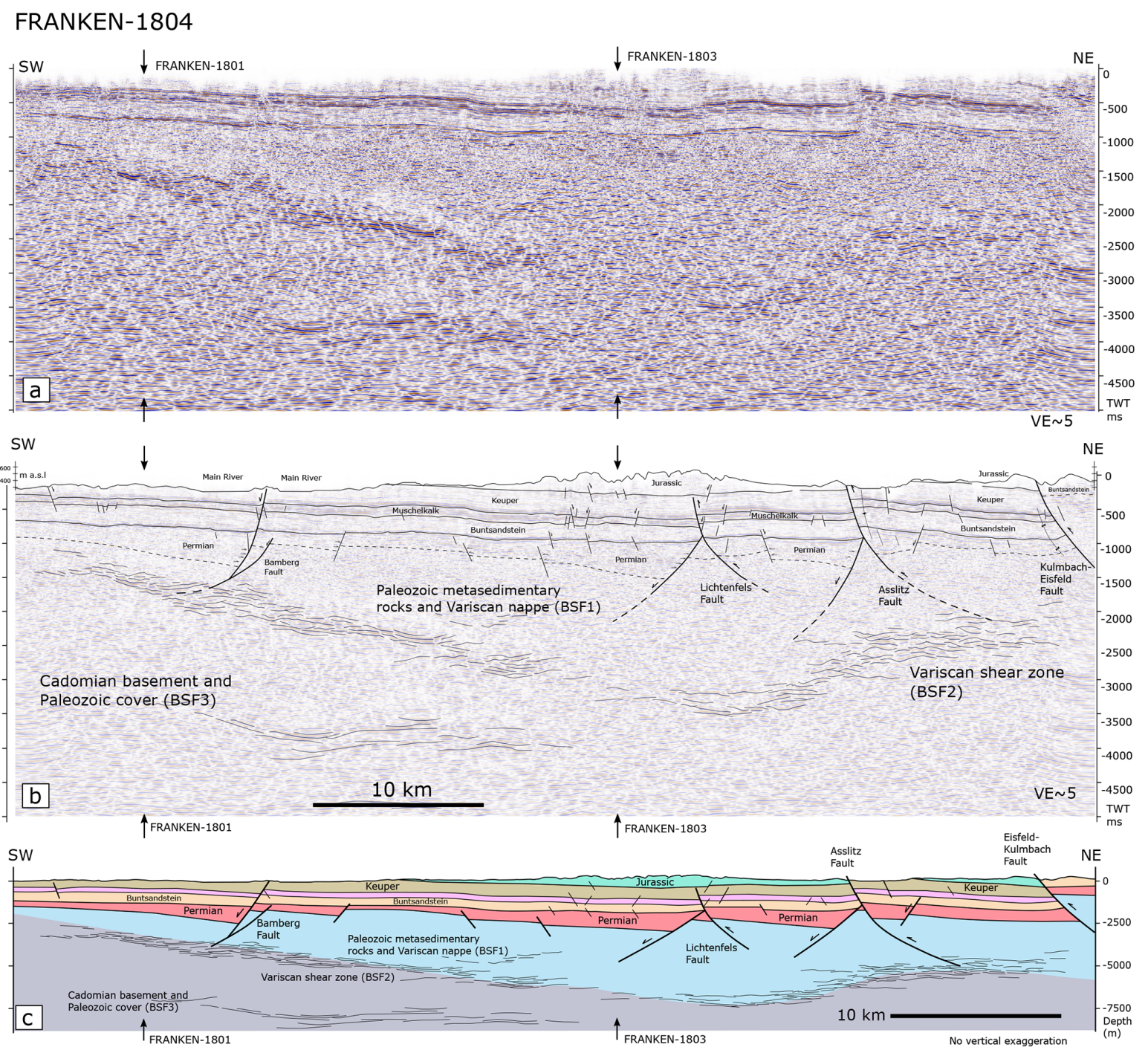

Figure 9. (a) Uninterpreted and (b) interpreted FRANKEN-1804 profile. Horizon interpretation along this profile is tied to the FRANKEN 1801 and 1803 intersection profiles. Note the overlapping reflections in the hanging wall of SW-dipping normal faults creating Permian half-grabens. (c) A depth-converted section with no vertical exaggeration. See Fig. 1 for the profile location.

phase and is related to the subduction and collision during the Variscan orogeny before ca. $340 \mathrm{Ma}$ (Kroner et al., 2007). For the assemblage of the Variscan during the subduction and collision, a NW tectonic transport under a NW-SE compression has also been proposed Franke and Stein (2000). Observed regional westward shallowing of mapped thrust shear zones west of the FFS could have been developed under both proposed tectonic transport directions. Seismic reflection data do not allow for the definition of a preferred tectonic transport direction; however, based on the kinematic indicators observed and described in the exposed parts of the Saxothuringian Zone, we tend to prefer the W-SW transport direction.

\subsection{Shear zone topography and strain localization during brittle deformation}

A regional NW-SE-dominated compressional and dextral transpressional phase at ca. $340-330 \mathrm{Ma}$ affected the Saxothuringian zone and most likely reactivated preexisting D1 shear zones, including the Münchberg Shear Zone (MSZ, Franke, 2000; Kroner et al., 2007). The 340-330 Ma deformation phase might have been responsible for modifying the initial geometry of the mapped shear zone by folding and bending (Figs. 7 and 9). Latest to post-orogenic normal faults appear to have developed at a wide range of vertical and lateral scales in response to the regional stress field. These normal faults propagated radially and created larger faults (e.g., Fazlikhani et al., 2021). However, only the ones that detach into the shear zone or preexisting thrust faults at depth grew 


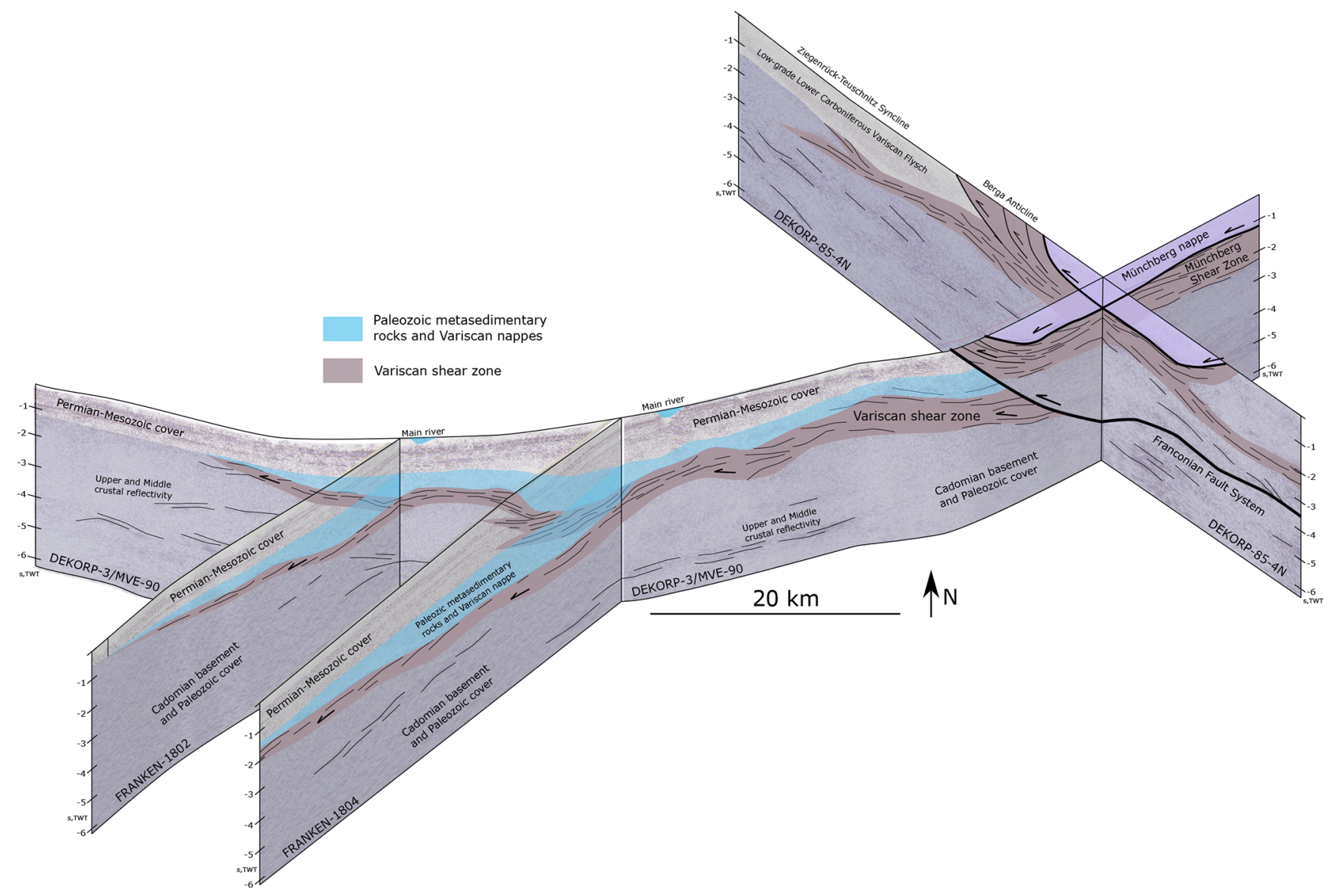

Figure 10. Present-day three-dimensional view of interpreted Variscan units and structures west of the Franconian Fault System (FFS). Variscan shear zone shows synformal and anti-formal geometries shallowing and thinning toward the W-SW.

further and potentially reactivated parts of the shear zone on their hanging wall side, while other normal faults became inactive (Figs. 7, 9 and 11b).

All the major reverse faults (Eisfeld-Kulmbach, Asslitz, Lichtenfels (northern portion) and Mürsbach) most likely developed in response to Cretaceous inversion events in central Europe (Kley and Voigt, 2008) and concentrate around the anti-formal parts of the shear zone. For example, along the FRANKEN-1802 profile, the Lichtenfels Fault developed on top of the folded portion of the underlying shear zone and it is exposed at the surface (Fig. 7). Conversely, ca. $10 \mathrm{~km}$ farther south along the FRANKEN-1804 profile where the underlying shear zone shows a rather flat geometry, the Lichtenfels Fault does not reach to the surface (Fig. 9). Similarly, the Mürsbach reverse fault in the footwall of the Bamberg normal fault (or a similar normal fault) developed on top of the folded portion of the shear zones and dies out laterally to the south where the shear zone is rather flat (Figs. 7 and 9). Our observations demonstrate that the anti-formal geometry of shear zones perturbs the regional stress field and localizes the strain, facilitating lateral and vertical growth of preferentially located brittle faults (Fig. 12). Comparable strain local- ization and brittle reactivation of orogenic shear zones during initiation and activity of post-orogenic brittle faults has been described from the post-Caledonian tectonics in Scandinavia (Fazlikhani et al., 2017; Phillips et al., 2016; Koehl et al., 2018; Wiest et al., 2020) and post-Variscan tectonics of the Western Alps (Festa et al., 2020; Ballèvre et al., 2018). The geometry of shear zones, which creates local ramps, also appears to influence the magnitude of fault offset in the study area. In the northeastern part of FRANKEN-1802 profile where the Variscan shear zone shows anti-formal geometry, the Lichtenfels Fault accumulates ca. $180 \mathrm{~ms}$ TWT of throw at the top Muschelkalk horizon and is exposed at the surface. Along the FRANKEN-1804 profile, ca. $10 \mathrm{~km}$ farther south, where the Variscan shear zone shows a rather flat geometry, the Lichtenfels Fault has only ca. $90 \mathrm{~ms}$ TWT of throw and is a blind fault tipping out in the Keuper units. In addition, the anti-formal parts of the shear zone generally experience more upper-crustal brittle deformation (normal and reverse faulting; Figs. 7 and 9). It should be noted that towards the east, at the margin of the Franconian Basin, the FFS as the major basin-bounding fault system displaces the basal detachment or shear zone, exposing Variscan basement 
(a) Present day

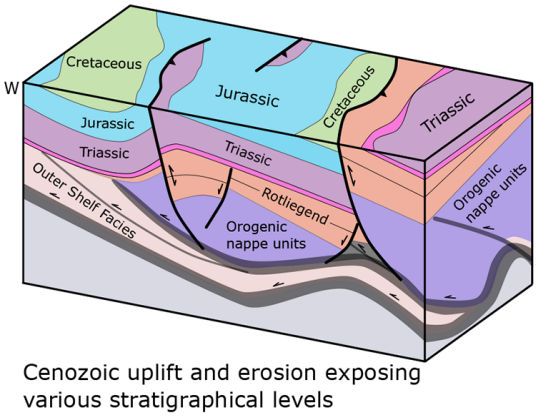

(b) Cretaceous

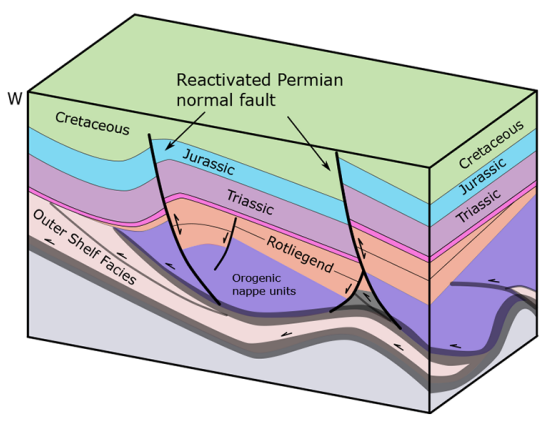

Cretaceous tectonic inversion and selective reverse reactivation of pre-existing (Permian) normal faults

(c) Triassic and Jurassic

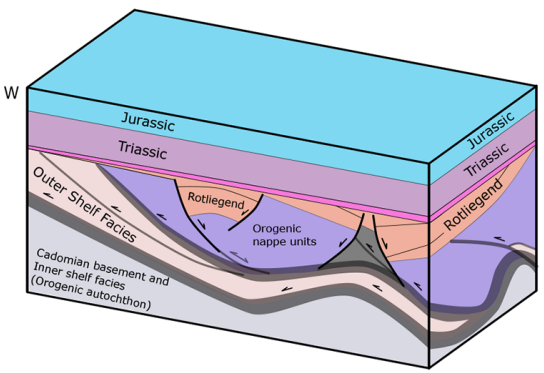

Early and middle Mesozoic regional tectonic quiescence (d) End of Permian

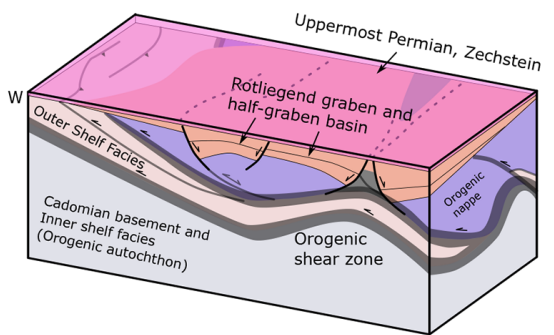

(e) Latest Carboniferous-Early Permian

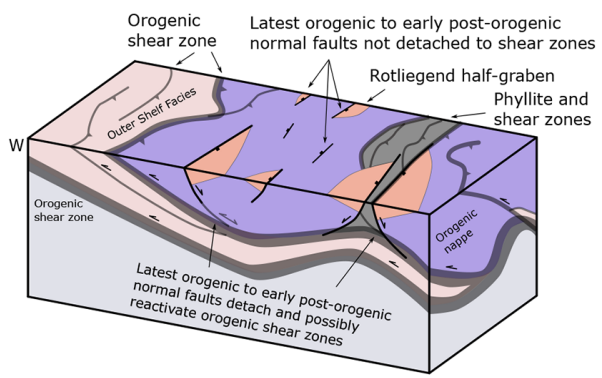

Nucleation and radial propagation of new faults perpendicular to regional stress field. Normal faults sub-parallel to preexisting orogenic shear zone grow while other normal faults eventually abandon.

\section{(f) End of orogeny (latest Carboniferous)}

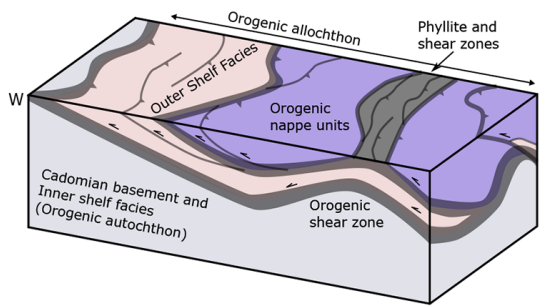

Figure 11. Simplified and generic cartoons showing the relationships between orogenic structures and post-orogenic fault and basin development (note that the shown general W-directed tectonic transport refers to the initial W-SW-directed nappe stacking). At the latest orogenic and early post-orogenic period, normal faults develop in response to the regional stress field, with some being sub-parallel to the preexisting orogenic structures. Some of the normal faults grow laterally, vertically detach into the underlying shear zones, and initiate graben and half-graben basins on their hanging wall side. Normal faults not detaching into preexisting shear zones are abandoned. After a Triassic and Jurassic regional tectonic quiescence, Cretaceous inversion events in Central Europe selectively reactivate Permian normal faults as steep reverse faults, exposing older stratigraphy in the hanging wall side and creating local synclines and anticlines in the vicinity of reactivated faults.

units in the hanging wall side. The fact that reverse faults accommodated a few hundred meters of offset and detach into shear zones, while the FFS, which accommodated ca. $3 \mathrm{~km}$ of offset (Wagner et al., 1997), displaces the shear zone, indicates that accumulation of a large amount of offset on a fault stimulates it to break through and displace the underlying shear zone. The amount of fault offset and the previously shown mechanical and rheological properties of shear zones, as well as their orientation relative to the extension and short- ening direction, are thus important controlling factors in the reactivation or displacement of the basal detachment or shear zone by brittle faults (Daly et al., 1989; Ring, 1994; Peace et al., 2018; Heilman et al., 2019; Phillips et al., 2019). 


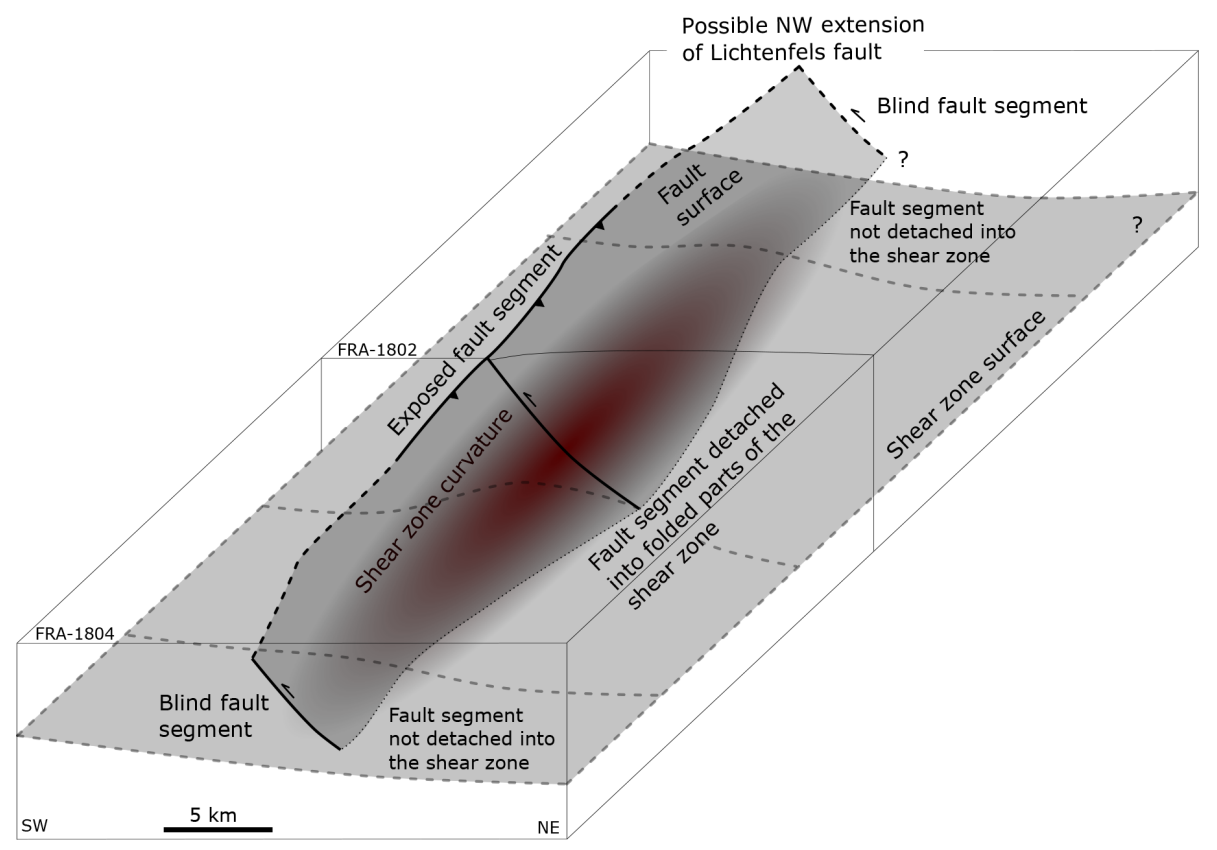

Figure 12. Cartoon showing the relationship between shear zone geometry and fault development. The dark red area in the center shows the folded part of the shear zone, where the Lichtenfels Fault portion is detached and exposed at the surface. Laterally to the SW, the shear zone is rather flat, and the Lichtenfels Fault thus does not detach and is not exposed at the surface.

\subsection{Post-Variscan Rotliegend basins in SE Germany and their regional context}

The latest stages of Variscan tectonics and post-orogenic thermal relaxation during the late Carboniferous and early Permian are marked by the development of intermontane basins in the internal parts of the Variscan belt (Arthaud and Matte, 1977; McCann et al., 2006). These intermontane basins are mainly located in the hanging wall of normal faults in graben and half-graben settings accumulating continental clastic sediments with rapid lateral thickness changes (McCann et al., 2006). Fault-bounded Rotliegend basins in SE Germany are also interpreted to have developed in an extensional and/or transtensional setting during latest Carboniferous and Permian times, as evidenced by rather abrupt lateral thickness and sedimentary facies changes across oblique slip normal faults (Schröder, 1988, 1987; Peterek et al., 1996b; Leitz and Schröder, 1985; Arthaud and Matte, 1977; Dill, 1988; Müller, 1994; Peterek et al., 1997; McCann et al., 2006; Helmkampf et al., 1982). Rotliegend sedimentary rocks in the study area are exposed in the footwall and hanging wall of the FFS from NW to SE in the Stockheim, Rugendorf, Wirsberg, and Weidenberg outcrops (Fig. 1). The Wolfersdorf well (Stockheim outcrop) drilled $726 \mathrm{~m}$ of Rotliegend, while the upper parts of the section are eroded, suggesting that even thicker Rotliegend sections (ca. $1000 \mathrm{~m}$ ) were originally deposited (Herrmann, 1958; Dill, 1988; Paul and Schröder, 2012). About $18 \mathrm{~km}$ west of the Wolfersdorf well, the Mittelberg well drilled only $41 \mathrm{~m}$ of Rotliegend be- fore reaching basement rocks (Friedlein and Hahn, 2018). Similar rapid thickness changes of the Rotliegend units were also observed in the Weidenberg, Erbendorf, Weiden, and Schmidgaden areas, all originally interpreted as small, isolated fault-bounded basins but now interpreted as individual exposures of one coherent depositional area, the NWSE Naab Basin, where the Rotliegend reaches up to $2800 \mathrm{~m}$ thickness (Paul and Schröder, 2012). The Naab Basin is bordered by normal faults, some of which were reactivated as reverse faults or crosscut by younger reverse faults (Müller, 1994).

In addition to exposures along the FFS, several wells in the western parts of the study area (e.g., Staffelstein 1, Mürsbach 1 and 6, and Eltmann) also encountered Rotliegend that relates to the SW-NE Kraichgau Basin (Table 1, Fig. 1), of which the NW-SE Naab Basin is considered a basin compartment (Paul, 2006). Among these wells, only Eltmann and Mittelberg reached the Rotliegend base showing a general westward thinning of Rotliegend units from the FFS (Table 1). This corresponds to the pattern of isopach maps, showing a gradual thickening of Rotliegend units to reach maximum thicknesses of ca. $2000 \mathrm{~m}$ in the easternmost parts of the Kraichgau Basin (Sittig and Nitsch, 2012).

Rotliegend basin architecture in the Variscan Internides, with the Saar-Nahe, Kraichgau, and Schramberg basins as prominent examples, is characterized by $10-100 \mathrm{~km}$ wide and long basins bordered by normal faults related to extensional forces rather than the collapse of over-thickened crust during the orogeny (Henk, 1997). In comparison, post- 
Caledonian Devonian basins in western Norway developed as supra-detachment basins that are bounded by brittle normal faults reactivating pre-existing Caledonian thrusts (Fossen, 2010; Fazlikhani et al., 2017; Wiest et al., 2020; Lenhart et al., 2019; Séranne and Séguret, 1987; Osmundsen and Andersen, 2001). Post-Caledonian supra-detachment basins in western Norway accumulate $>26 \mathrm{~km}$ of Devonian units that are almost 3 times greater than the true depth of the basin (Vetti and Fossen, 2012; Séranne and Séguret, 1987). In the northern North Sea and its western margin onshore Scotland and Shetland and the offshore East Shetland Platform, post-Caledonian Devonian basins are interpreted as normal fault-bounded half-graben basins that in some cases detach onto Caledonian thrust or shear zones (Coward et al., 1989; Platt and Cartwright, 1998; Fazlikhani et al., 2017; Norton et al., 1987; Séranne, 1992; Patruno et al., 2019; Phillips et al., 2019; Fazlikhani et al., 2021).

The range of post-orogenic basin architecture observed in Caledonian and Variscan orogens highlights the importance of preexisting orogenic thrust and shear zones. Comparison of post-Caledonian basins with post-Variscan basins shows that in the Caledonian cases pre-existing detachment and shear zones play a more important role in basin development and architecture than in the post-Variscan basins, as observed in the study area. Normal faults bounding postVariscan basins appear not to reactivate entire Variscan thrust and shear zones, except for the Saar-Nahe Basin (Henk, 1993). Observed variations in post-orogenic basin architecture might be related to the differences in the exposed level of the basement. Exposed Devonian basins of western Norway show deeper levels of crust in comparison to Devonian basins in the western margin of the North Sea rift. It should be noted that the post-orogenic extension direction relative to the orientation of the orogenic structures in addition to the amount and duration of the post-orogenic extension also influence basin architecture.

\subsection{Brittle fault development and relative age relationships}

Post-Variscan extensional phases resulted in the development of normal faults bounding Rotliegend half-graben and graben basins observed across the Variscan belt (Peterek et al., 1997; Arthaud and Matte, 1977; McCann et al., 2006; Schröder, 1987; Müller, 1994; Stephenson et al., 2003). Mapped seismic-scale normal faults in the study area can be divided into three main groups based on their stratigraphic position: (I) normal faults developed at shallower depth that terminate in the lower Triassic or upper Permian (Zechstein) intervals (Figs. 6-9), (II) normal faults developed in the deeper parts of the stratigraphy displacing Permian units and continuing into the pre-Permian units with their upper tip terminating in uppermost Permian (Zechstein) or lowermost Triassic units (e.g., normal faults in the footwall of Lichtenfels and Asslitz reverse faults, Figs. 6-9), and (III) small groups of normal faults that displace the entire stratigraphy and die out into the pre-Permian units (Figs. 6 and 9).

The first group of normal faults, which developed in the Triassic units only, do not show synsedimentary activity detectable in seismic profiles and are interpreted to most likely originate from sedimentary loading and differential compaction during a regional tectonic quiescence in Triassic and Jurassic times (Peterek et al., 1997; Fazlikhani et al., 2021; Fazlikhani and Back, 2015). The second group of normal faults, mainly displacing the Permian succession, is interpreted to have developed during post-orogenic extension in latest Carboniferous-Permian (Stephanian-Rotliegend) time. This second group of normal faults shows widespread evidence of synsedimentary activity and bounding Permian half-graben and graben basins (buried and exposed) in southern Germany. In the majority of cases the first and second groups of normal faults are not hard-linked vertically. This observation can be explained by the presence of fine-grained marine and (in some places) evaporitic Zechstein units acting as a semi-ductile to ductile layer to accommodate strain. However, in few instances the Zechstein, together with Triassic units, is displaced by the third group of normal faults (Figs. 6 and 9). It should be noted that with the available dataset it is not clear whether the third group of normal faults is the result of an up-section growth of Permian faults or down-section growth of the Triassic-Jurassic faults or whether they developed due to the down-section growth of Triassic-Jurassic faults linking to and reactivating preexisting Permian faults.

In addition to normal faults, the major kilometer-long NW-SE-striking Eisfeld-Kulmbach, Asslitz, Lichtenfels, and Mürsbach reverse faults are located west of the FFS, displacing and folding the Permian to Jurassic sedimentary cover. Reverse faults are better developed in the eastern part of the study area and on top of the anti-formal parts of the Variscan shear zones, while towards the west normal faults dominate. Observed reverse faults are developed mainly in the footwalls of Permian normal faults and dip to the E-NE (Figs. 6-9). Reverse faults cut through the upper portion of Permian normal faults, translating Permo-Mesozoic units to the W-SW. Farther north of the study area in the Thuringian Basin and northern Germany, similar reverse faults are related to the Cretaceous inversion event (Kley and Voigt, 2008; Navabpour et al., 2017). Therefore, it appears that the youngest generation of seismic-scale brittle faults are the reverse faults. However, whether reverse faults only initiated during the Cretaceous inversion and younger events or are instead reverse reactivated eastward-dipping Permian normal faults is still unclear and needs further investigation.

\section{Conclusion}

In this study we combine existing 2D seismic reflection profiles, well data, and surface geological information to in- 
terpret the recently acquired 2D FRANKEN seismic survey in SE Germany. Three basement seismic facies (BSF13) are described below the Permian-Mesozoic sedimentary cover and are interpreted as Variscan units and structures. We investigate the possible westward continuation of Variscan units and structures and discuss the influence of Variscan structures in latest to post-Variscan basin development. We come to the following conclusions based on this investigation.

- Variscan units and structures extend to $\sim 65 \mathrm{~km}$ west of the FFS beneath sedimentary rocks of the Kraichgau and Franconian basins.

- Low-grade metasedimentary rocks and possible nappe units (BSF1) in the hanging wall of Variscan shear zones are wedge shaped and thin out towards the WSW.

- Variscan autochthons occupy the footwalls of shear zones.

- Shear zones show local synformal and anti-formal geometries and reach to the base of the Permian-Mesozoic sedimentary cover towards the $\mathrm{W}-\mathrm{SW}$.

- The geometry of shear zones controls the location at which major Permian normal faults have developed.

- Permian normal faults dip in various directions, creating Rotliegend graben and half-graben basins. Observed Rotliegend half-graben basins in the east are interpreted as the NW continuation of the Naab Basin. Towards the west, interpreted Rotliegend units are associated with the Kraichgau Basin.

- The thickness of Triassic sedimentary rocks is fairly constant, highlighting a period of tectonic quiescence in the study area.

- Some of the Permian normal faults are crosscut by oppositely dipping reverse faults that most likely appeared during the regional Cretaceous inversion event that occurred in central Europe. Some of the reverse faults are interpreted as reactivated preexisting Permian normal faults, while others might have been developed during the Cretaceous inversion event.

- Reverse reactivated normal faults are restricted to the eastern parts of the study area where preexisting Variscan shear zone show synformal and anti-formal geometries.

We document the westward continuation of Variscan shear zones away from the Bohemian Massif for the first time and show how the geometry of shear zones localize the strain and influence the development of latest to post-orogenic faults and basins.
Data availability. DEKORP seismic data are available from the GFZ (Deutsches GeoForschungsZentrum) Potsdam upon request. Utilized well data can be made available through the Geological Survey of Bavaria (Bayerisches Landesamt für Umwelt - LfU) upon request. FRANKEN seismic data are acquired for the ongoing Geothermal Alliance Bavaria (GAB) research project and are not yet publicly available.

Author contributions. HF integrated utilized datasets, interpreted the seismic reflections, and prepared the manuscript. WB planned and managed the seismic data acquisition. WB and HS acquired the financial support and contributed to the reviewing, improvement, and discussion of the presented results.

Competing interests. The contact author has declared that neither they nor their co-authors have any competing interests.

Disclaimer. Publisher's note: Copernicus Publications remains neutral with regard to jurisdictional claims in published maps and institutional affiliations.

Acknowledgements. This contribution is part of the Geothermal Alliance Bavaria $(\mathrm{GAB})$ project, which funded by grants from the Bavarian State Ministry of Education and Cultural Affairs, Science and Art provided to the Friedrich-Alexander University ErlangenNürnberg (FAU), the Technical University of Munich (TUM), and the University of Bayreuth. We would like to thank the Bayerisches Landesamt für Umwelt (LfU) for providing well data and fruitful discussions. Schlumberger is thanked for providing academic licenses for Petrel and supporting the "3D Lab" at the FriedrichAlexander University. The authors would like to thank the members of the GAB project for the discussions they provided, which increased the quality of this contribution. The topical editor Virginia Toy, reviewers Jonas Kley and Uwe Kroner, an anonymous referee, and Jean-Baptiste Koehl are thanked for their comments, which greatly improved the quality of our manuscript.

Financial support. This research has been supported by grants from the Bavarian State Ministry of Education and Cultural Affairs, Science and Art provided to the Friedrich-Alexander University Erlangen-Nürnberg (FAU), the Technical University of Munich (TUM), and the University of Bayreuth.

Review statement. This paper was edited by Virginia Toy and reviewed by Uwe Kroner, Jonas Kley, and one anonymous referee.

\section{References}

Arthaud, F. and Matte, P.: Late Paleozoic strike-slip faulting in southern Europe and northern Africa: Result of a rightlateral shear zone between the Appalachians and the Urals, 
GSA Bulletin, 88, 1305-1320, https://doi.org/10.1130/00167606(1977)88<1305:LPSFIS>2.0.CO;2, 1977.

Bader, K. and Bram, K. (Eds.): Der mittelfränkische Gebirgsrücken südlich Nürnberg: Geologischer Rahmen, geophysikalische Untersuchungen und Ergebnisse von Forschungsbohrungen, Geologisches Jahrbuch Reihe E, Band E 58, Schweizerbart and Borntraeger, Stuttgart, Germany, ISBN 978-3-510-95873-3, 2001.

Ballèvre, M., Manzotti, P., and Dal Piaz, G. V.: Pre-Alpine (Variscan) Inheritance: A Key for the Location of the $\mathrm{Fu}-$ ture Valaisan Basin (Western Alps), Tectonics, 37, 786-817, https://doi.org/10.1002/2017TC004633, 2018.

Behr, H. J. and Heinrichs, T.: Geological interpretation of DEKORP 2-S: A deep seismic reflection profile across the Saxothuringian and possible implications for the Late Variscan structural evolution of Central Europe, Tectonophysics, 142, 173-202, https://doi.org/10.1016/0040-1951(87)90122-3, 1987.

Bergerat, F. and Geyssant, J.: Tectonique cassante et champ de contraintes tertiaire en avant des Alpes orientales: le Jura souabe, Geol. Rundsch., 71, 537-548, 1982.

Boy, J. A., Haneke, J., Kowalczyk, G., Lorenz, V., Schindler, T., Stollhofen, H., and Thum, H.: Rotliegend im Saar-Nahe-Becken, am Taunus-Südrand und im nördlichen Oberrheingraben, in: Innervariscische Becken, edited by: Lützner, H., Schriftenreihe der Deutschen Gesellschaft für Geowissenschaften (SDGG), Heft 61, Schweizerbart and Borntraeger, Stuttgart, Germany, 254377, ISBN 978-3-510-49225-1, 2012.

Buness, H.-A. and Bram, K.: Die Muschelkalkoberfläche und die permische Peneplain in Mittelfranken abgeleitet aus seismischen Messungen, in: Der mittelfränkische Gebirgsrücken südlich Nürnberg: Geologischer Rahmen, geophysikalische Untersuchungen und Ergebnisse von Forschungsbohrungen, edited by: Bader, K. and Bram, K., Geologisches Jahrbuch Reihe E, Band E 58, Schweizerbart and Borntraeger, Stuttgart, Germany, 35-59, ISBN 978-3-510-95873-3, 2001.

Carlé, W.: Bau und Entwicklung der Südwestdeutschen Großscholle, Beihefte zum Geologischen Jahrbuch, Schweizerbart and Borntraeger, ISBN 978-3-510-96825-1, 1955.

Cassinis, G., Toutin-Morin, N., and Virgili, C.: A General Outline of the Permian Continental Basins in Southwestern Europe, in: The Permian of Northern Pangea: Volume 2: Sedimentary Basins and Economic Resources, edited by: Scholle, P., Peryt, T. M., and Ulmer-Scholle, D. S., Springer, Berlin, 137-157, ISBN 139783540573524, 1995.

Chateauneuf, J. J. and Farjanel, G.: Synthèse Géologique des Bassins Permiens Français, 128th Edn., Bureau de recherches ge'ologiques et minie'res, ISBN 271590455X, 1989.

Collanega, L., Siuda, K., A.-L. Jackson, C., Bell, R. E., Coleman, A. J., Lenhart, A., Magee, C., and Breda, A.: Normal fault growth influenced by basement fabrics: The importance of preferential nucleation from pre-existing structures, Basin Res., 31, 659-687, https://doi.org/10.1111/bre.12327, 2019.

Coubal, M., Málek, J., Adamovič, J., and Štěpančíková, P.: Late Cretaceous and Cenozoic dynamics of the Bohemian Massif inferred from the paleostress history of the Lusatian Fault Belt, J. Geodyn., 87, 26-49, https://doi.org/10.1016/j.jog.2015.02.006, 2015.

Coward, M. P., Enfield, M. A., and Fischer, M. W.: Devonian basins of Northern Scotland: extension and inversion related to Late
Caledonian - Variscan tectonics, Geol. Soc. Lond. Spec. Publ., 44, 275, https://doi.org/10.1144/GSL.SP.1989.044.01.16, 1989.

Daly, M. C., Chorowicz, J., and Fairhead, J. D.: Rift basin evolution in Africa: the influence of reactivated steep basement shear zones, Geol. Soc. Lond. Spec. Publ., 44, 309-334, https://doi.org/10.1144/GSL.SP.1989.044.01.17, 1989.

DEKORP and Orogenic Processes Working Group: Structure of the Saxonian Granulites: Geological and geophysical constraints on the exhumation of high-pressure/high-temperature rocks in the mid-European Variscan belt, Tectonics, 18, 756-773, https://doi.org/10.1029/1999TC900030, 1999.

DEKORP Research Group: Crustal structure of the Saxothuringian Zone: Results of the deep seismic profile MVE-90(East), Z. Geol. Wissenschaft., 22, 647-769, 1994a.

DEKORP Research Group: DEKORP 3/MVE 90(West) - preliminary geological interpretation of a deep near-vertical reflection profile between the Rhenish and Bohemian Massifs, Germany, Z. Geol. Wissenschaft., 22, 771-801, 1994b.

Dill, H.: Sedimentpetrographie des Stockheimer Rotliegendbeckens, Nordostbayern, Geologisches Jahrbuch Reihe D, Band D 88, Schweizerbart and Borntraeger, Stuttgart, Germany, ISBN 9783-510-96103-0, 1988.

Eberts, A., Fazlikhani, H., Bauer, W., Stollhofen, H., de Wall, H., and Gabriel, G.: Late to post-Variscan basement segmentation and differential exhumation along the SW Bohemian Massif, central Europe, Solid Earth, 12, 2277-2301, https://doi.org/10.5194/se-12-2277-2021, 2021.

Edel, J. B. and Weber, K.: Cadomian terranes, wrench faulting and thrusting in the central Europe Variscides: geophysical and geological evidence, Geol. Rundsch., 84, 412-432, https://doi.org/10.1007/BF00260450, 1995.

Ehling, B.-C. and Gebhardt, U.: Rotliegend im Saale-Becken, in: Innervariscische Becken, edited by: Lützner, H., Schriftenreihe der Deutschen Gesellschaft für Geowissenschaften (SDGG), Heft 61, Schweizerbart and Borntraeger, Stuttgart, Germany, 504516, ISBN 978-3-510-49225-1, 2012.

Emmert, U., Gudden, H., Haunschild, H., Meyer, R. K. F., Schmid, H., Schuh, H., and Stettner, G.: Bohrgut-Beschreibung der Forschungsbohrung Obernsees, Geologica Bavarica, 88, 23-47, 1985.

Engel, W., Feist, R., and Franke, W.: Le Carbonifère antéStéphanien de la Montagne Noire: rapports entre mise en place des nappes et sédimentation, Bulletin du BRGM, 1, 341-389, 1982.

Fazlikhani, H. and Back, S.: The influence of differential sedimentary loading and compaction on the development of a deltaic rollover, Mar. Petrol. Geol., 59, 136-149, https://doi.org/10.1016/j.marpetgeo.2014.08.005, 2015.

Fazlikhani, H., Fossen, H., Gawthorpe, R. L., Faleide, J. I., and Bell, R. E.: Basement structure and its influence on the structural configuration of the northern North Sea rift, Tectonics, 36, 11511177, https://doi.org/10.1002/2017TC004514, 2017.

Fazlikhani, H., Aagotnes, S. S., Refvem, M. A., Hamilton-Wright, J., Bell, R. E., Fossen, H., Gawthorpe, R. L., Jackson, C. A.-L., and Rotevatn, A.: Strain migration during multiphase extension, Stord Basin, northern North Sea rift, Basin Res., 33, 1474-1496, https://doi.org/10.1111/bre.12522, 2021.

Festa, A., Balestro, G., Borghi, A., de Caroli, S., and Succo, A.: The role of structural inheritance in continen- 
tal break-up and exhumation of Alpine Tethyan mantle (Canavese Zone, Western Alps), Geosci. Front., 11, 167-188, https://doi.org/10.1016/j.gsf.2018.11.007, 2020.

Fossen, H.: Extensional tectonics in the North Atlantic Caledonides: a regional view, Geol. Soc. Lond. Spec. Publ., 335, 767-793, https://doi.org/10.1144/SP335.31, 2010.

Franke, W.: Tectonostratigraphic units in the Variscan belt of central Europe, in: Terranes in the Circum-Atlantic Paleozoic Orogens, edited by: Dallmeyer, R. D., Geological Society of America, 6791, https://doi.org/10.1130/SPE230-p67, 1989.

Franke, W.: The mid-European segment of the Variscides: tectonostratigraphic units, terrane boundaries and plate tectonic evolution, in: Orogenic Processes: Quantification and Modelling in the Variscan Belt, edited by: Franke, W., Haak, V., Oncken, O., and Tanner, D. C., 179, 35, https://doi.org/10.1144/GSL.SP.2000.179.01.05, 2000.

Franke, W. and Stein, E.: Exhumation of high-grade rocks in the Saxo-Thuringian Belt: Geological constraints and geodynamic concepts, Geol. Soc. Lond. Spec. Publ., 179, 337, https://doi.org/10.1144/GSL.SP.2000.179.01.20, 2000.

Franke, W., Behrmann, J., and Moehrmann, H.: Zur Deformationsgeschichte des Kristallins im Münchberger Deckenstapel, KTB Report, 92-4, Schweizerbart and Borntraeger, 225-240, ISBN 978-3-928-55907-2, 1992.

Franke, W., Haak, V., Oncken, O., and Tanner, D. C. (Eds.): Orogenic Processes: Quantification and Modelling in the Variscan Belt, Geol. Soc. Lond. Spec. Publ., 179, https://doi.org/10.1144/GSL.SP.2000.179, 2000.

Franke, W., Cocks, L. R. M., and Torsvik, T. H.: The Palaeozoic Variscan oceans revisited, Gondwana Res., 48, 257-284, https://doi.org/10.1016/j.gr.2017.03.005, 2017.

Franz, M., Nowak, K., Berner, U., Heunisch, C., Bandel, K., Röhling, H.-G., and Wolfgramm, M.: Eustatic control on epicontinental basins: The example of the Stuttgart Formation in the Central European Basin (Middle Keuper, Late Triassic), Global Planet. Change, 122, 305-329, https://doi.org/10.1016/j.gloplacha.2014.07.010, 2014.

Freudenberger, W. and Schwerd, K.: Erläuterungen zur Geologischen Karte von Bayern 1. Geol. :500000, Bayerisches Geologisches Landesamt, München, 1996.

Freudenberger, W., Herold, B., and Wagner, S.: BohrkernBeschreibung und Stratigraphie der Forschungsbohrungen Lindau 1 und Spitzeichen 1, Geologica Bavarica, 109, 15-26, 2006.

Friedlein, V. and Hahn, T.: Mittelberg well description: Internal report, Bayerisches Landesamt fuer Umwelt, 2018.

Gudden, H.: Über die Struktur Mürsbach und ihre Eignung für behälterlose unterirdische Gasspeicherung, München, 1971.

Gudden, H.: Die Thermal-Mineralwasser-Erschließungsbohrung Staffelstein 1975, Brunnenbau, Bau von Wasserwerken und Rohrleitungsbau (bbr), 28, 85-92, 1977.

Gudden, H.: Der Untere Keuper in Bohrungen zwischen Eltmann und Rodach, Geologische Blätter von Nordost-Bayern, 31, 448462,1981

Gudden, H.: Der Buntsandstein in der Forschungsbohrung Obernsees, Geologica Bavarica, 88, 69-81, 1985.

Gudden, H. and Schmid, H.: Die Forschungsbohrung Obernsees-Konzeption, Durchführung und Untersuchung der Metallführung, Geologica Bavarica, 88, 5-21, 1985.
Hahn, T., Kroner, U., and Mezer, P.: Lower Carboniferous synorogenic sedimentation in the Saxo-Thuringian Basin and the adjacent Allochthonous Domain, in: Pre-Mesozoic geology of SaxoThuringia: From the Cadomian active margin to the Variscan orogen, edited by: Linnemann, U. and Romer, R. L., Schweizerbart and Borntraeger, Stuttgart, 171-192, ISBN 978-3-510-65259-4, 2010.

Hallas, P., Pfänder, J. A., Kroner, U., and Sperner, B.: Microtectonic control of ${ }^{40} \mathrm{Ar} /{ }^{39} \mathrm{Ar}$ white mica age distributions in metamorphic rocks (Erzgebirge, N-Bohemian Massif): Constraints from combined step heating and multiple single grain total fusion experiments, Geochim. Cosmochim. Ac., 314, 178-208, https://doi.org/10.1016/j.gca.2021.08.043, 2021.

Haunschild, H.: Der Keuper in der Forschungsbohrung Obernsees, Geologica Bavarica, 88, 103-130, 1985.

Heilman, E., Kolawole, F., Atekwana, E. A., and Mayle, M.: Controls of Basement Fabric on the Linkage of Rift Segments, Tectonics, 38, 1337-1366, https://doi.org/10.1029/2018TC005362, 2019.

Heinrichs, T., Giese, P., and Bankwitz, E.: DEKORP 3/MVE-90 (West) Preliminary geological interpretation of a deep nearvertical reflection profile between the Rhenish and the Bohemian Massifs, Germany, Z. Geol. Wissenschaft., 22, 771-801, 1994.

Helmkampf, K. E.: Profilvergleich und sedimentologische Entwicklung im Umkreis der Forschungsbohrungen Spitzeichen 1 und Lindau 1, Geologica Bavarica, 109, 63-94, 2006.

Helmkampf, K. E., Kuhlmann, J., and Kaiser, D.: Das Rotliegende im Bereich der Weidener Bucht, in: Geologica Bavarica 83: Neue Tiefbohrungen in Bayern, Bayerisches Geologisches Landesamt, München, 167-186, 1982.

Henk, A.: Gravitational orogenic collapse vs plate-boundary stresses: a numerical modelling approach to the PermoCarboniferous evolution of Central Europe, Geol. Rundsch., 86, 39-55, https://doi.org/10.1007/s005310050120, 1997.

Henk, A.: Late orogenic Basin evolution in the Variscan internides: the Saar-Nahe Basin, southwest Germany, Tectonophysics, 223, 273-290, https://doi.org/10.1016/0040-1951(93)90141-6, 1993.

Herrmann, R.: Die stratigraphichen und tektonischen Verhältnisse des Stockheimer Beckens, Geologie, 7, 133-157, 1958.

Heuse, T., Blumenstengel, H., Elicki, O., Geyer, G., Hansch, W., Maletz, J., Sarmiento, G. N., and Weyer, D.: Biostratigraphy The faunal province of the southern margin of the Rheic Ocean, in: Pre-Mesozoic geology of Saxo-Thuringia: From the Cadomian active margin to the Variscan orogen, edited by: Linnemann, U. and Romer, R. L., Schweizerbart and Borntraeger, Stuttgart, 99-170, ISBN 978-3-510-65259-4, 2010.

Hirschmann, G.: KTB - The structure of a Variscan terrane boundary: seismic investigation - drilling - models, Tectonophysics, 264, 327-339, https://doi.org/10.1016/S0040-1951(96)00171-0, 1996.

Kley, J. and Voigt, T.: Late Cretaceous intraplate thrusting in central Europe: Effect of Africa-Iberia-Europe convergence, not Alpine collision, Geology, 36, 839-842, https://doi.org/10.1130/G24930A.1, 2008.

Koehl, J.-B. P., Bergh, S. G., Henningsen, T., and Faleide, J. I.: Middle to Late Devonian-Carboniferous collapse basins on the Finnmark Platform and in the southwesternmost Nordkapp basin, SW Barents Sea, Solid Earth, 9, 341-372, https://doi.org/10.5194/se9-341-2018, 2018. 
Köhler, S., Duschl, F., Fazlikhani, H., Koehn, D., Stephan, T., and Stollhofen, H.: Reconstruction of cyclic Mesozoic-Cenozoic stress development in Southeastern Germany using fault-slip and stylolite inversion, Geological Magazine, in review, 2022.

Kossmat, F.: Gliederung des varistischen Gebirgsbaues, Abhandlungen des Sächsischen Geologischen Landesamtes, 1, 1-39, 1927.

Krohe, A.: Variscan tectonics of central Europe: Postaccretionary intraplate deformation of weak continental lithosphere, Tectonics, 15, 1364-1388, https://doi.org/10.1029/96TC01110, 1996.

Kroner, U., Hahn, T., Romer, R. L., and Linnemann, U.: The Variscan orogeny in the Saxo-Thuringian zone - Heterogenous overprint of Cadomian/Paleozoic Peri-Gondwana crust, in: The Evolution of the Rheic Ocean: From AvalonianCadomian Active Margin to Alleghenian-Variscan Collision, edited by: Linnemann, U., Nance, R. D., Kraft, P., and Zulauf, G., Geological Society of America, 153-172, https://doi.org/10.1130/2007.2423(06), 2007.

Kroner, U. and Goerz, I.: Variscan assembling of the Allochthonous Domain of the Saxo-Thuringian Zone - a tectonic model, in: Pre-Mesozoic geology of Saxo-Thuringia: From the Cadomian active margin to the Variscan orogen, edited by: Linnemann, U. and Romer, R. L., Schweizerbart and Borntraeger, Stuttgart, 271286, ISBN 978-3-510-65259-4, 2010.

Laversanne, J.: Le Permian de Lodeve (Massif Central Francais). Evolution des depots Autuniens et exemples de mineralisations uraniferes diagenetiques par circulation de solutions exogenes, Sciences de la Terre, 22, 109-178, 1978.

Leitz, F. and Schröder, B.: Die Randfazies der Trias und Bruchschollenland südöstlich Bayreuth (Exkursion C am 11. und 12. April 1985), Jahresberichte und Mitteilungen des Oberrheinischen Geologischen Vereins, 67, 51-63, https://doi.org/10.1127/jmogv/67/1985/51, 1985.

Lenhart, A., Jackson, C. A.-L., Bell, R. E., Duffy, O. B., Gawthorpe, R. L., and Fossen, H.: Structural architecture and composition of crystalline basement offshore west Norway, Lithosphere, 11, 273-293, https://doi.org/10.1130/L668.1, 2019.

Linnemann, U. and Heuse, T.: The Ordovician of the Schwarzburg Anticline: Geotectonic setting, biostratigraphy and sequence stratigraphy (Saxo-Thuringian Terrane, Germany), Zeitschrift der Deutschen Geologischen Gesellschaft, 151, 471-491, https://doi.org/10.1127/zdgg/151/2001/471, 2001.

Linnemann, U. and Romer, R. L. (Eds.): Pre-Mesozoic geology of Saxo-Thuringia: From the Cadomian active margin to the Variscan orogen, Schweizerbart and Borntraeger, Stuttgart, 488 pp., ISBN 978-3-510-65259-4, 2010.

Linnemann, U., Hofmann, M., Romer, R. L., and Gerdes, A.: Transitional stages between the Cadomian and Variscan orogenies: Basin development and tectono-magmatic evolution of the southern margin of the Rheic Ocean in the Saxo-Thuringian Zone (North Gondwana shelf), in: Pre-Mesozoic geology of SaxoThuringia: From the Cadomian active margin to the Variscan orogen, edited by: Linnemann, U. and Romer, R. L., Schweizerbart and Borntraeger, Stuttgart, 59-98, ISBN 978-3-510-652594, 2010.

Lüschen, E., Wenzel, F., Sandmeier, K.-J., Menges, D., Rühl, T., Stiller, M., Janoth, W., Keller, F., Söllner, W., Thomas, R., Krohe, A., Stenger, R., Fuchs, K., Wilhelm, H., and Eisbacher, G.: Near- vertical and wide-angle seismic surveys in the Black Forest, SW Germany, J. Geophys., 62, 1-30, 1987.

Lützner, H., Andreas, D., Schneider, J. W., Voigt, S., and Werneburg, R.: Stefan und Rotliegend im Türinger Wald und seiner Umgebung, in: Innervariscische Becken, edited by: Lützner, H., Schriftenreihe der Deutschen Gesellschaft für Geowissenschaften (SDGG), Heft 61, Schweizerbart and Borntraeger, Stuttgart, Germany, 418-487, ISBN 978-3-510-49225-1, 2012.

Matter, A., Peters, T. J., Bläsi, H. R., and and Ziegler, H. J.: Sondierbohrung Riniken, in: NAGRA Technischer Bericht, Switzerland radioactive waste disposal, 1-214, https://www.nagra.ch/en/ technischer-bericht-86-02 (last access: 21 February 2022), 1987.

McCann, T., Pascal, C., Timmerman, M. J., Krzywiec, P., López-Gómez, J., Wetzel, L., Krawczyk, C. M., Rieke, H., and Lamarche, J.: Post-Variscan (end CarboniferousEarly Permian) basin evolution in Western and Central Europe, Geol. Soc. Lond. Mem., 32, 355-388, https://doi.org/10.1144/GSL.MEM.2006.032.01.22, 2006.

Meissner, R., Wever, T., and Bittner, R.: Results of DEKORP 2-S and other reflection profiles through the Variscides, Geophys. J. Int., 89, 319-324, https://doi.org/10.1111/j.1365246X.1987.tb04425.x, 1987.

Meyer, R. K. F.: Der Jura in der Forschungsbohrung Obernsees, Geologica Bavarica, 88, 131-135, 1985.

Müller, M.: Neue Vorstellungen zur Entwicklung des Nordostbayerischen Permokarbon-Trogs aufgrund reflexionsseismischer Messungen in der Mittleren Oberpfalz, Geologische Blätter von Nordost-Bayern, 44, 195-224, 1994.

Navabpour, P., Malz, A., Kley, J., Siegburg, M., Kasch, N., and Ustaszewski, K.: Intraplate brittle deformation and states of paleostress constrained by fault kinematics in the central German platform, Tectonophysics, 694, 146-163, https://doi.org/10.1016/j.tecto.2016.11.033, 2017.

Norton, M. G., McClay, K. R., and Way, N. A.: Tectonic evolution of Devonian basins in northern Scotland and southern Norway, Norw. J. Geol., 67, 323-338, 1987.

Osagiede, E. E., Rotevatn, A., Gawthorpe, R., Kristensen, T. B., Jackson, C. A.-L., and Marsh, N.: Pre-existing intra-basement shear zones influence growth and geometry of non-colinear normal faults, western Utsira HighHeimdal Terrace, North Sea, J. Struct. Geol., 130, 103908, https://doi.org/10.1016/j.jsg.2019.103908, 2019.

Osmundsen, P. T. and Andersen, T. B.: The middle Devonian basins of western Norway: sedimentary response to largescale transtensional tectonics?, Tectonophysics, 332, 51-68, https://doi.org/10.1016/S0040-1951(00)00249-3, 2001.

Patruno, S., Reid, W., Berndt, C., and Feuilleaubois, L.: Polyphase tectonic inversion and its role in controlling hydrocarbon prospectivity in the Greater East Shetland Platform and Mid North Sea High, UK, Geol. Soc. Lond. Spec. Publ., 471, 177, https://doi.org/10.1144/SP471.9, 2019.

Paul, J.: Rotliegend und unterer Zechstein der Forschungsbohrung Lindau 1 (NE-Bayern), Geologica Bavarica, 109, 27-48, 2006.

Paul, J. and Schröder, B.: Rotliegend im Ostteil der Süddeutschen Scholle, in: Innervariscische Becken, edited by: Lützner, H., Schriftenreihe der Deutschen Gesellschaft für Geowissenschaften (SDGG), Heft 61, Schweizerbart and Borntraeger, Stuttgart, Germany, 697-706, ISBN 978-3-510-49225-1, 2012. 
Peace, A., McCaffrey, K., Imber, J., van Hunen, J., Hobbs, R., and Wilson, R.: The role of pre-existing structures during rifting, continental breakup and transform system development, offshore West Greenland, Basin Res., 30, 373-394, https://doi.org/10.1111/bre.12257, 2018.

Peterek, A., Rauche, H., and Schröder, B.: Die strukturelle Entwicklung des E-Randes der Süddeutschen Scholle in der Kreide, Z. Geol. Wissenschaft., 24, 65-77, 1996a.

Peterek, A., Schröder, B., and Menzel, D.: Zur postvariszischen Krustenentwicklung des Naabgebirges und seines Rahmens, Z. Geol. Wissenschaft., 24, 293-304, 1996 b.

Peterek, A., Rauche, H., Schröder, B., Franzke, H.-J., Bankwitz, P., and Bankwitz, E.: The late-and post-Variscan tectonic evolution of the Western Border fault zone of the Bohemian massif (WBZ), Geol. Rundsch., 86, 191-202, https://doi.org/10.1007/s005310050131, 1997.

Phillips, T. B. and McCaffrey, K. J. W.: Terrane Boundary Reactivation, Barriers to Lateral Fault Propagation and Reactivated Fabrics: Rifting Across the Median Batholith Zone, Great South Basin, New Zealand, Tectonics, 38, 4027-4053, https://doi.org/10.1029/2019TC005772, 2019.

Phillips, T. B., Jackson, C. A.-L., Bell, R. E., Duffy, O. B., and Fossen, H.: Reactivation of intrabasement structures during rifting: A case study from offshore southern Norway, J. Struct. Geol., 91, 54-73, https://doi.org/10.1016/j.jsg.2016.08.008, 2016.

Phillips, T. B., Fazlikhani, H., Gawthorpe, R. L., Fossen, H., Jackson, C. A.-L., Bell, R. E., Faleide, J. I., and Rotevatn, A.: The Influence of Structural Inheritance and Multiphase Extension on Rift Development, the NorthernNorth Sea, Tectonics, 38, 40994126, https://doi.org/10.1029/2019TC005756, 2019.

Platt, N. H. and Cartwright, J. A.: Structure of the East Shetland Platform, northern North Sea, Petrol. Geosci., 4, 353, https://doi.org/10.1144/petgeo.4.4.353, 1998.

Ravidà, D. C. G., Caracciolo, L., Henares, S., Janßen, M., and Stollhofen, H.: Drainage and environmental evolution across the Permo-Triassic boundary in the south-east Germanic Basin (north-east Bavaria), Sedimentology, 69, 501-536, https://doi.org/10.1111/sed.12913, 2021.

Ring, U.: The influence of preexisting structure on the evolution of the Cenozoic Malawi rift (East African rift system), Tectonics, 13, 313-326, https://doi.org/10.1029/93TC03188, 1994.

Schönig, J., Eynatten, H. von, Meinhold, G., Lünsdorf, N. K., Willner, A. P., and Schulz, B.: Deep subduction of felsic rocks hosting UHP lenses in the central Saxonian Erzgebirge: Implications for UHP terrane exhumation, Gondwana Res., 87, 320-329, https://doi.org/10.1016/j.gr.2020.06.020, 2020.

Schröder, B.: Inversion tectonics along the Western margin of the Bohemian Massif, Tectonophysics, 137, 93-100, https://doi.org/10.1016/0040-1951(87)90316-7, 1987.

Schröder, B.: Outline of the Permo-Carboniferous Basins at the Western Margin of the Bohemian Massif, Z. Geol. Wissenschaft., 16, 993-1001, 1988.

Schuh, H.: Der Zechstein in der Forschungsbohrung Obernsees, Geologica Bavarica, 88, 57-68, 1985.

Schwan, W.: Die sächsischen Zwischengebirge und Vergleiche mit der Münchberger Gneismasse und anderen analogen Kristallinvorkommen im Saxothuringikum, Erlanger geologische Abhandlungen, Heft 99, Erlangen: s.n, 180 pp., 11 leaves of plates, ISSN 0071-1160, 1974.
Séranne, M.: Devonian extensional tectonics versus Carboniferous inversion in the northern Orcadian basin, Journal of the Geological Society, 149, 27, https://doi.org/10.1144/gsjgs.149.1.0027, 1992.

Séranne, M. and Séguret, M.: The Devonian basins of western Norway: tectonics and kinematics of an extending crust, Geol. Soc. Lond. Spec. Publ., 28, 537, https://doi.org/10.1144/GSL.SP.1987.028.01.35, 1987.

Sittig, E. and Nitsch, E.: Stefan und Rotliegend zwichen Odenwald und Alpenrand, in: Innervariscische Becken, edited by: Lützner, H., Schriftenreihe der Deutschen Gesellschaft für Geowissenschaften (SDGG), Heft 61, Schweizerbart and Borntraeger, Stuttgart, Germany, 646-696, ISBN 978-3-510-49225-1, 2012.

Specht, S.: Eltmann well description: Internal report, Bayerisches Landesamt fuer Umwelt, 2018.

STD: Die Stratigraphische Tabelle von Deutschland, Deutsche Stratigraphische Kommission (DSK), ISBN 978-3-9816597-7-1, 2016.

Stephan, T., Kroner, U., Hahn, T., Hallas, P., and Heuse, T.: Fold/cleavage relationships as indicator for late Variscan sinistral transpression at the Rheno-Hercynian-Saxo-Thuringian boundary zone, Central European Variscides, Tectonophysics, 681, 250-262, https://doi.org/10.1016/j.tecto.2016.03.005, 2016.

Stephenson, R. A., Narkiewicz, M., Dadlez, R., van Wees, J.D., and Andriessen, P.: Tectonic subsidence modelling of the Polish Basin in the light of new data on crustal structure and magnitude of inversion, Sediment. Geol., 156, 59-70, https://doi.org/10.1016/S0037-0738(02)00282-8, 2003.

Stettner, G.: Metamorphism and Tectonics in the Münchberg Mass and the Fichtelgebirge, Fortschr. Mineral., 52, 59-69, 1974.

Stettner, G. and Salger, M.: Das Schiefergebirge in der Forschungsbohrung Obernsees, Geologica Bavarica, 88, 49-55, 1985.

Stollhofen, H.: Facies architecture variations and seismogenic structures in the Carboniferous-Permian Saar-Nahe Basin (SW Germany): evidence for extension-related transfer fault activity, Sediment. Geol., 119, 47-83, https://doi.org/10.1016/S00370738(98)00040-2, 1998.

Strugale, M., Da Schmitt, R. S., and Cartwright, J.: Basement geology and its controls on the nucleation and growth of rift faults in the northern Campos Basin, offshore Brazil, Basin Res., 33, 1906-1933, https://doi.org/10.1111/bre.12540, 2021.

Trusheim, F.: Über den Untergrund Frankens; Ergebnisse von Tief Bohrungen in Franken und Nachbargebieten, Geologica Bavarica, 54, 1-106, 1964.

Vasconcelos, D. L., Bezerra, F. H., Medeiros, W. E., Castro, D. L. de, Clausen, O. R., Vital, H., and Oliveira, R. G.: Basement fabric controls rift nucleation and postrift basin inversion in the continental margin of NE Brazil, Tectonophysics, 751, 23-40, https://doi.org/10.1016/j.tecto.2018.12.019, 2019.

Vetti, V. V. and Fossen, H.: Origin of contrasting Devonian supradetachment basin types in the Scandinavian Caledonides, Geology, 40, 571-574, https://doi.org/10.1130/G32512.1, 2012.

von Freyberg, B.: Tektonische Karte der Fränkischen Alb und ihrer Umgebung, Erlanger Geologische Abhandlungen, 77, 1$81,1969$.

von Gümbel, C. W.: Geognostische Beschreibung des Königreichs Bayern. Dritte Abtheilung. Geognostische Beschreibung des Fichtelgebirges mit dem Frankenwalde und dem westlichen Vor- 
lande, Perthes, Dr. Friedrich Pfeil, Gotha, ISBN 978-3-93151638-3, 1879.

Wagner, G. A., Coyle, D. A., Duyster, J., Henjes-Kunst, F., Peterek, A., Schröder, B., Stöckhert, B., Wemmer, K., Zulauf, G., Ahrendt, H., Bischoff, R., Hejl, E., Jacobs, J., Menzel, D., Lal, N., van den Haute, P., Vercoutere, C., and Welzel, B.: Post-Variscan thermal and tectonic evolution of the KTB site and its surroundings, J. Geophys. Res., 102, 18221-18232, https://doi.org/10.1029/96JB02565, 1997.

Wemmer, K.: K-Ar-Altersdatierungsmöglichkeiten für retrograde Deformationsprozesse im spröden und duktilen BereichBeispiele aus der KTB -Vorbohrung (Oberpfalz) und dem Bereich der Insubrischen Linie (N-Italien), Göttinger Arbeiten Zur Geologie und Paläontologie, 51, 1-61, 1991.

Wever, T., Meissner, R., and Sadowiak, P.: Deep reflection seismic data along the central part of the European Geotraverse in Germany: a review, Tectonophysics, 176, 87-101, https://doi.org/10.1016/0040-1951(90)90260-F, 1990.

Wiest, J. D., Wrona, T., Bauck, M. S., Fossen, H., Gawthorpe, R. L., Osmundsen, P. T., and Faleide, J. I.: From Caledonian Collapse to North Sea Rift: The Extended History of a Metamorphic Core Complex, Tectonics, 39, e2020TC006178, https://doi.org/10.1029/2020TC006178, 2020.
Wrona, T., Fossen, H., Lecomte, I., Eide, C. H., and Gawthorpe, R. L.: Seismic expression of shear zones: Insights from 2-D pointspread-function-based convolution modelling, J. Struct. Geol., 140, 104121, https://doi.org/10.1016/j.jsg.2020.104121, 2020.

Ye, Q., Mei, L., Shi, H., Du, J., Deng, P., Shu, Y., and Camanni, G.: The Influence of Pre-existing Basement Faults on the Cenozoic Structure and Evolution of the Proximal Domain, Northern South China Sea Rifted Margin, Tectonics, 39, e2019TC005845, https://doi.org/10.1029/2019TC005845, 2020.

Ziegler, P. A.: Tectonic and palaeogeographic development of the North Sea rift system, Tectonic Evolution of North Sea Rifts, edited by: Blundell, D. J. and Gibbs, A., Clarendon Press, Oxford, 1-36, 1990. 